Article

\title{
Application of Non-Destructive Techniques on a Varve Sediment Record from Vouliagmeni Coastal Lake, Eastern Gulf of Corinth, Greece
}

\author{
Alexandros Emmanouilidis ${ }^{1}\left(\mathbb{0}\right.$, Ingmar Unkel ${ }^{2}{ }^{(0}$, Joana Seguin ${ }^{2}$, Kleoniki Keklikoglou ${ }^{3,4}{ }^{\oplus}$, \\ Eleni Gianni ${ }^{1}$ (D) and Pavlos Avramidis ${ }^{1, * \mathbb{D}}$ \\ 1 Department of Geology, University of Patras, 26504 Rio Patras, Greece; a.emmanouilidis@g.upatras.gr (A.E.); \\ elengian93@gmail.com (E.G.) \\ 2 Institute for Ecosystem Research, Christian-Albrechts-University, 24118 Kiel, Germany; \\ iunkel@ecology.uni-kiel.de (I.U.); jseguin@ecology.uni-kiel.de (J.S.) \\ 3 Hellenic Centre for Marine Research, Institute of Marine Biology, Biotechnology and Aquaculture, \\ 71500 Heraklion, Greece \\ 4 Department of Biology, University of Crete, 71500 Heraklion, Greece; keklikoglou@hcmr.gr \\ * Correspondence: p.avramidis@upatras.gr
}

Received: 18 October 2020; Accepted: 19 November 2020; Published: 21 November 2020

\begin{abstract}
During the last few decades, X-ray attenuation systems have been established as standard techniques in geosciences and as excellent scientific tools for the analysis of sedimentary facies and structures. In the present study, we use two non-destructive and high-resolution systems (computed tomography, X-ray fluorescence) to address all sedimentological facies and structural characteristics on a $6 \mathrm{~m}$ long, partly laminated sediment record, from Vouliagmeni lake, located at the eastern part of the Corinth Gulf, Greece. Vouliagmeni lake is the deepest coastal lake in Greece, and its location is of great importance since it is located in one of the most tectonically active regions in the world. The chronological framework of the retrieved sediment sequence spans the last 12,000 years, with alternations of laminated and non-laminated sections. The annual accumulation of the laminated sequences was determined through the radionuclide concentration of 14 samples. Scanning tomography was performed with a medical CT scanner and a $\mu \mathrm{CT}$ scanner, aiming to compare the potentials and variations of both methods. Lamination boundaries, event layers (turbidites) and sediment deformations were distinguished through processing the extracted 3D rendered volumes, after applying ranges depending on Hounsfield (HU) values. Microscopic analysis revealed three main layer types in the varve sequences that were examined, attributing to summer/spring, autumn and winter deposits. Statistical analysis of the elemental composition, magnetic susceptibility (MS) measurements and $\mathrm{HU}$ values revealed three clusters/facies, reflecting climatic and in-lake hydrological changes. Cluster A emulates sedimentation during arid conditions, while Cluster B reflects humid conditions with increased precipitation and erosion. Cluster C represents sequences with homogenous Ca-rich sediment. Our proposed workflow highlights the possible correlation between the non-destructive variables that were measured, but also the variations and applications of each method and software used during this study.
\end{abstract}

Keywords: computed tomography; XRF scanning; laminations; Holocene; sedimentological facies; Hounsfield values

\section{Introduction}

Holocene archives of the Eastern Mediterranean region are shaped by complex topography and climate heterogeneity, combined with increasing human impact on the landscape since the 
Mid-Holocene. Since geodynamic forces do not change drastically during the lifespan of archives such as lakes and lagoons, sedimentation processes seem to be mainly controlled by climatic modulations and anthropogenic interference. Studies conducted in the Eastern Mediterranean on lacustrine environments [1-11] and lagoons [12-17] present intricate patterns of alternating sedimentological facies, mirroring global or local-scale paleoclimatic/paleoenvironmental events and changes.

Depending on the prevailing conditions in a lake catchment, accumulation of annual sedimentation layers (varves) may occur. The importance of annually laminated sediments in paleoclimatic studies has been highlighted by many authors (for an extensive review, see [18] and [19]) since they can provide high-resolution chronostratigraphic records. Recent studies conducted on varved sediment records [20] focus on lake water conditions [21,22], pollen records [23], sediment characteristics [24,25] and analogue approaches [26]. The lack of bioturbation on the lake bottom, stratification of the water column, lack of tectonic activity and gravity originated sediment relocation are some of the most common parameters controlling laminae preservation. Hence, the conservation of such delicate structures is rare and, most of the time, difficult, due to the high number of factors that have to remain constant; hence, varve sequences are often incomplete or interrupted, e.g., [27-30].

In Greece, Holocene varved sediment archives have only been recorded in the Aetoliko lagoon [31-33]. Changes in precipitation and solar irradiance were reflected in varve thickness and isotopic composition, with a significant climatic transition during the 18th century [34]. The main reasons behind the deficiency of varved records could be attributed to (1) complex topography and atmospheric patterns that lead to the spatial and temporal diversion of climate and (2) extensive tectonic activity disturbing regular sediment accumulation.

Differentiating sedimentological facies in such complex sediment sequences requires high-resolution analyses with the combined use of different techniques. Non-destructive X-ray-based systems like X-ray fluorescence (XRF) scanning and computed tomography (CT)/ $\mu$-computed tomography scanning $(\mu \mathrm{CT})$ have been widely used since their introduction in the last decades, as common and hence standard techniques, because they can potentially provide information concerning elemental distribution [35-41], sediment structural characteristics [42-46], density [47] and porosity [48-53] without disturbing/destroying the sediment sequence. Both X-ray-based systems are subject to the same principles since they emit X-rays onto a sediment sample. During the elemental analysis, the XRF system measures the wavelength of the electromagnetic waves produced by secondary electrons of each element. In contrast, in CT scanning, the system calculates the absorption of the X-ray beam from each atom it passes (attenuation coefficient). The interaction between radiation/matter and the absorption/fluorescence ratio (Compton/Rayleigh) is highly dependent on sample thickness, density, elemental composition, and X-ray energy [54].

In this study, we present a partly laminated sediment record from Vouliagmeni coastal lake, located at the eastern part of the Gulf of Corinth in Greece, covering the last 12,000 years BP. Preliminary results of this study focusing on CT scan analysis were published in [55]. The core location is one of the most seismically active regions in the world [56]. Combined with the general lack of laminated records in Greece, this signifies the importance of this sediment record in Eastern Mediterranean paleoenvironmental research. We apply a multi-proxy analysis with a combined use of X-ray systems (XRF, CT and $\mu \mathrm{CT}$ scanning) and standard sedimentological techniques, aiming to recognize all sedimentary facies and structures in the core but, also, to address the imprint of environmental changes in the system during the Holocene. The workflow and methodology used during this study will include the use of multiple types of computer software and different approaches that will be thoroughly described to potentially provide guidance and assistance in future research.

\section{Study Area}

The study area is located in southern Greece (Figure 1a) and specifically in the eastern part of the Gulf of Corinth (Figure 1b). The gulf is an active continental rift, with extension rates around $10-15 \mathrm{~mm} / \mathrm{yr}[57,58]$ with numerous catastrophic events recognized in the coastal zone $[59,60]$. The first 
results published from the International Ocean Discovery Program (IODP) Expedition 381, which took place from October to December 2017 in the eastern part of the gulf, indicate continuous cycles between marine and isolated conditions of the gulf over the last $700 \mathrm{ka}$, depending primarily on eustatic high and low stands [61]. Changes in sediment accumulation and bottom water conditions have been assumed so far to be climatically driven [61]. Environmental changes recorded in the coastal areas [62-66] seem to be linked to the gulf's tectonic activity, from which submarine landslides are triggered [67-71].

Vouliagmeni coastal lake, situated in SW Perachora Peninsula ( $\left.38^{\circ} 1.714^{\prime} \mathrm{N}, 22^{\circ} 52.850^{\prime} \mathrm{E}\right)$, is formed through a tectonic depression and is highly affected by a complex fault system (Figure 1c). The former status of the Vouliagmeni tectonic graben as a bay during the Late Pleistocene was terminated through the tectonic uplift of the area, around the end of the last glacial period [72]. Through a narrow $(18 \mathrm{~m})$ canal that was constructed during the 19th century, the lake has been artificially forced into a more lagoonal state, due to constant interaction with the gulf since then. However, observations of Lithophaga shells in the west coast of Vouliagmeni lake indicate that even in antiquity, the lake water corresponded to that of the sea [73]. The total surface area of the lake is approximately $1.5 \mathrm{~km}^{2}$ and the maximum depth $49 \mathrm{~m}$. The steep bathymetry, especially at the northern and southern part of the lake, is shaped by normal dipping faults located at the north and south side of the lake (Figure 1c). The drainage system of the Perachora peninsula is attributed to two main networks (Perachora and Pissia) that present different types of evolutionary development [74]. Below $35 \mathrm{~m}$ water depth, hypoxic conditions seem to prevail in the lake [75]. The mean water surface temperature is $22^{\circ} \mathrm{C}$, whereas the bottom temperature ranges from 10 to $14{ }^{\circ} \mathrm{C}$. The spatial distribution of surficial sediment characteristics and their connection with the hydrodynamic regime have been studied by [76].

The Perachora peninsula belongs to the Boeotian geotectonic zone [77] and is characterized by complex fault systems that strike E-W to ENE-WSW and WNW-ESE (for an extensive geological overview of the area, see [74]). The basement consists of limestones, volcanic and clastic marine deposits (conglomerates/sandstones) (Figure 1c) that are all subjected to massive, tectonically driven movement. Activation of the normal dipping fault systems has been recorded since antiquity [72], causing massive earthquakes and landform dislocation at around 4600-4000 BP, 8th century BCE, 6th and 4th century BCE and 2nd century CE. Holocene coastal deposits comprise the lake surrounding coastal area and are mostly extended in the eastern part. 


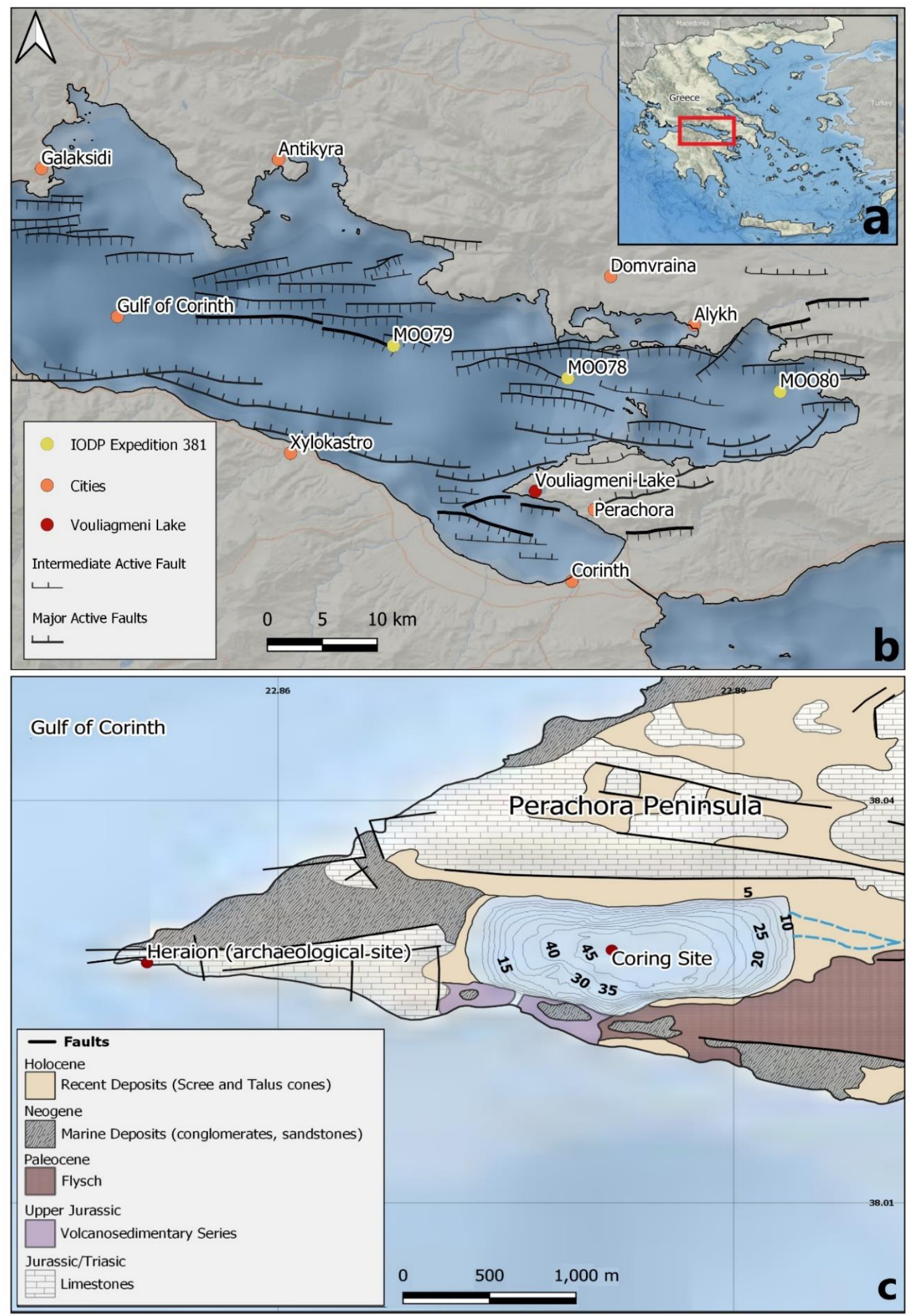

Figure 1. (a) Map of Greece with the study area highlighted. (b) Map of the eastern part of the Gulf of Corinth, presenting the major fault systems (modified from [78]), cities, IODP expedition 381, and the study area. (c) Simplified geological map of the study area based on geological mapping from Hellenic Survey of Geology and Mineral Exploration. 


\section{Materials and Methods}

\subsection{Core Sampling}

During the field campaign in April 2018, one $6 \mathrm{~m}$ long sediment core and a $4 \mathrm{~m}$ long parallel one were retrieved from the deepest part of the lake $(\sim 46 \mathrm{~m})\left(38^{\circ} 1.740^{\prime} \mathrm{N} 22^{\circ} 52.920^{\prime} \mathrm{E}\right)$ using a Usinger piston corer system [79] and a wire-operated second platform at the lake bottom. Coring equipment was provided by the Institute of Ecosystem Research, Kiel University, Germany. After the extraction, the cores were cut into $1 \mathrm{~m}$ sections, split, and macroscopically examined for the first overview concerning sediment structure, color and texture, and then stored in cool rooms $\left(4^{\circ} \mathrm{C}\right)$ in the Department of Geology, University of Patras, Greece.

\subsection{Sedimentology/Mineralogy}

Standard sedimentological analyses were conducted on 60 samples from the sediment core ( $\sim 10 \mathrm{~cm}$ resolution). Grain size distribution was established through a Malvern Mastersizer, Hydro 2000, with the classification established according to [80]. $\mathrm{CaCO}_{3}$ content was determined using a FOG II/Digital Hand-Held Calcimeter (BD Inventions) using a modified method from [81] and [82]. Magnetic susceptibility measurements were conducted through a Bartington MS2E system, with a step size of $1 \mathrm{~cm}$ throughout the sediment sequence. Sediment color was determined by extracting the RGB spectrum through ImageJ software.

X-ray diffraction (Brucker D8 Advance) with $\mathrm{Cu}-\mathrm{K}$-alpha radiation $(\lambda=1.5418 \mathrm{~A})$ and Nickel filter was used for the characterization of the mineralogical composition of the sediment samples. Crystallographica Search-Match v 2.0.3.1 (COxford Cryosystems Ltd, UK.) software was used for the qualitative analysis of the samples, with the identified minerals further verified with TOPAS software v.3. The semi-quantitative analysis of the minerals was performed via the same software, excluding the clay minerals due to the error of the method. For the quantification of clay minerals, the Area method was used [83]. The final percentages of the minerals in the sediment samples (including the clay fraction) were obtained via normalization. Due to the detection limit of the XRD system $(2-3 \%)$, minerals that were $<3 \%$ in the sediment samples were not detected, and for this reason, only semi-quantitative analysis is possible.

\subsection{CT Scanning/Thin Sections}

Medical computed tomography was conducted for each core segment $(1 \mathrm{~m})$ separately, using a Toshiba Aquilion Prime CT scanner, at the University of Patras, Greece. Acquisition parameters were set as follows: $0.5 \mathrm{~mm}$ slice thickness, $0.3 \mathrm{~mm}$ slice interval, helical rotation with pitch factor $0.637,120 \mathrm{kV}$ and $350 \mathrm{~mA}$. For enhancement of the output data, during the rendering process, the soft tissue and bone algorithms were used. Each algorithm provides a different setting; thus, both approaches were examined and compared for better visualization of the sediment structures. Each core segment scanned $(\sim 1 \mathrm{~m})$ produced 3500-4100 DICOM files when the scanner was set at the highest possible resolution.

Micro-CT scanning was performed at the Hellenic Centre for Marine Research (HCMR) using a Skyscan 1172 micro-tomograph (Bruker, Kontich, Belgium). The scanner uses a tungsten X-ray source which is equipped with an 11 PM CCD camera $(4000 \times 2672$ pixel). The sample was scanned at a voltage of $100 \mathrm{kV}$ and a current of $100 \mu \mathrm{A}$ with a combination of aluminum and copper filter and a pixel size of $13.79 \mu \mathrm{m}$ for a half rotation of $180^{\circ}$. Projection images were reconstructed into cross-section images using the SkyScan's NRecon software (NRecon, Bruker, Kontich, Belgium), which implements a modified Feldkamp's back-projection algorithm. Subsequently, the reconstructed images were loaded into the software CT Analyser v.1.18.4.0 + (CTAn, Bruker, Kontich, Belgium) to calculate the mean grayscale value, which represents the relative density of the sample. Furthermore, 3D analysis of the scanned sample was performed by using the custom processing plugin of CTAn software to calculate the $3 \mathrm{D}$ thickness of the sample. For optimization of the exported data, all samples during both CT scanning methods were scanned "wet" [45]. 
Three representative thin sections $(4.3 \times 2.3 \mathrm{~cm})$ were prepared using standard techniques, including embedding in epoxy resin, and grinding, aiming to underline potential variations and advantages/disadvantages between CT scanning and microscopic analysis. Microscopic examination was performed through a petrographic microscope at 100-400× magnification.

\subsection{Elemental Composition}

Downcore elemental variations were measured by an Avaatech X-Ray Fluorescence core scanner, on the split core surfaces, at the Institute of Geosciences, Kiel University. The core segments were covered with a high-purity polypropylene film and then scanned with $5 \mathrm{~mm}$ resolution and a rhodium $\mathrm{X}$-ray source. Two separate runs were conducted, the first at $10 \mathrm{kV}$ and $10 \mathrm{sec}$ exposure time for the elements $\mathrm{Al}, \mathrm{Si}, \mathrm{S}, \mathrm{Cl}, \mathrm{K}, \mathrm{Ca}, \mathrm{Ti}, \mathrm{Mn}, \mathrm{Fe}$ and a second scan at $30 \mathrm{kV}$ and $15 \mathrm{sec}$ exposure time for the elements $\mathrm{Zn}, \mathrm{Rb}, \mathrm{Sr}, \mathrm{Zr}$. Measured elemental intensities were all plotted as ratios rather than absolute concentrations, to avoid closed-sum effects [84,85].

\subsection{CT Scan Workflow}

Core segments were first scanned with a Nikon line scan camera, and high-resolution digital photos were acquired. These photos were used for a first evaluation of the laminated sequence, with reference (top/bottom depth) of each laminated section. Since the Lake Vouliagmeni core presents distinct organic (black) and calcite (white) laminations, RGB colors and a grayscale profile were also extracted through ImageJ software, providing an even clearer distinction of laminated sections' boundaries.

Each point scanned through CT is characterized by a specific "signal", which is expressed in Hounsfield units (HU). Medical CT scanners, similar to the one used in this study, are set with a $\mathrm{HU}$ value of -1000 for air and 0 for water. Apart from sediment internal structural characteristics, the correlation between $\mathrm{HU}$ and the sediment density/atomic composition can provide a fast overview and distinction between sedimentological facies, thus sections where different sedimentological processes prevail in the lake. For recognition of each laminae boundary, the HU ranges of the calcite/white and organic/black laminations were detected through INOBITEC medical software and SedCT software [86]. During the examination in all core sections, the PVC tube from the core, as well as the first $1 \mathrm{~mm}$ of the core surface, were excluded from the 2D rendered volume, to prevent miscounting of $\mathrm{HU}$ values due to oxidization and sediment deformation from core splitting. By presenting each time the HU range of each lamination type while excluding the non-laminated deposits, in the 3D model, the exact lamination number was measured by the automated software Cybis Coordinate Recorder (CooRecorder; http:/www.cybis.se/cbeewing/index.htm) and BMPix and Peak tools [87]. Additionally, laminations were counted manually by extracting 2D image sections, setting a scale and then measuring each lamination separately. A total of $\sim 3230$ laminations were calculated in the core by using both proposed methods. No significant variations were observed between the different software used, except some minor miscounts of Cybis Coordinate recorder, in sections where lamination boundaries in the core surface were deformed during splitting.

Event sedimentation into the system was examined through 4 main criteria on the non-laminated deposits, including (1) HU values, (2) magnetic susceptibility, (3) Mn content and (4) potential inverse grading. Then, 3D models were constructed by selecting regions of interest (ROI) in the Avizo Fire (Thermo Fisher) software and by projecting them with the frequency distribution and grayscale colourmap. Both HU and MS present high values at the base of the turbidite deposits [88-90].

\subsection{Core Chronology}

The chronological framework of the core was established through 10 accelerator mass spectrometry (AMS) radiocarbon samples, analyzed in Poznan Radiocarbon Laboratory (Poland) and Beta Analytic, Dublin (Ireland) (Table 1). Three different types of sample material were chosen due to the lack of datable organic material in some sections. Whenever it was possible, charcoal samples or sediment with high organic compounds were preferred for dating. In sections where this was not possible, 
bivalve shells (Cerastoderma glaucum) were selected with the criteria of being intact and showing no sign of transport. Shell samples were also thoroughly washed with distilled water and placed in an ultrasonic bath for around $30 \mathrm{~min}$, removing any residue sediment from the valves. Due to the lack of data concerning the exact reservoir correction on the Gulf of Corinth, all shell samples were treated with a $\Delta \mathrm{R}$ correction of $89 \pm 58$ years [91].

Table 1. List of radiocarbon samples from Lake Vouliagmeni core. Calibrated ages are presented in median values and were determined using IntCal13 calibration dataset [92]. ${ }^{*}=$ Marine reservoir correction as suggested by [91].

\begin{tabular}{cccccc}
\hline Lab no. & Sample Name & Sample Type & ${ }^{14}$ C date & Error & cal BP \\
\hline Poz-106723 & VOUL_0.79 & Charcoal & 455 & 30 & 514 \\
Poz-106910 & VOUL_1.85 & Charcoal & 1905 & 30 & 1841 \\
Poz-106912 & VOUL_2.67 & Wood & 2440 & 30 & 2667 \\
Poz-107143 & VOUL_2.92* & Shell & 2890 & 35 & $3026^{*}$ \\
Poz-111943 & VOUL_3.88 & Organic Sediment & 4700 & 35 & 5431 \\
Beta-543038 & VOUL_4.18 & Organic Sediment & 5720 & 30 & 6444 \\
Poz-107144 & VOUL_4.72* & Shell & 7770 & 40 & $8460^{*}$ \\
Beta-543039 & VOUL_5.20 & Organic Sediment & 8360 & 30 & 9406 \\
Poz-107146 & VOUL_5.72* & Shell & 9910 & 50 & $11,244 *$ \\
Poz-107047 & VOUL_5.91* & Shell & 10,260 & 60 & $11,832^{*}$ \\
\hline
\end{tabular}

For the investigation of the annual mechanism of deposition in the laminated sections, 14 dried sediment samples ( $1 \mathrm{~cm}$ thickness) were tested for radionuclides concentration in teleDOS Labs (ISO 11929:2010). The artificial radionuclides ${ }^{137} \mathrm{Cs}$ and ${ }^{241} \mathrm{Am}$, as well as the natural ${ }^{238} \mathrm{U}$ decay series, were measured using Broad Energy Germanium detectors (BEGe-5030 with carbon window) of Canberra-Eurisys.

\section{Results}

\subsection{Core Description}

The Vouliagmeni core is characterized by a complex stratigraphy, with alternating laminated and non-laminated deposits (Figure 2). Sediment color (RGB) presented in \% of all spectrums, has the highest values in the white $\left(\mathrm{CaCO}_{3}\right)$ laminations and lowest values in the non-laminated deposits (Figure 2). The 8-bit image used for the grayscale analysis also displays the maximum values ( 200) in the same regions. Laminated sediments occur throughout the sediment core but present a higher frequency from 220 to $430 \mathrm{~cm}$. The mean thickness of the laminated sections in the core is around $9 \mathrm{~cm}$. 


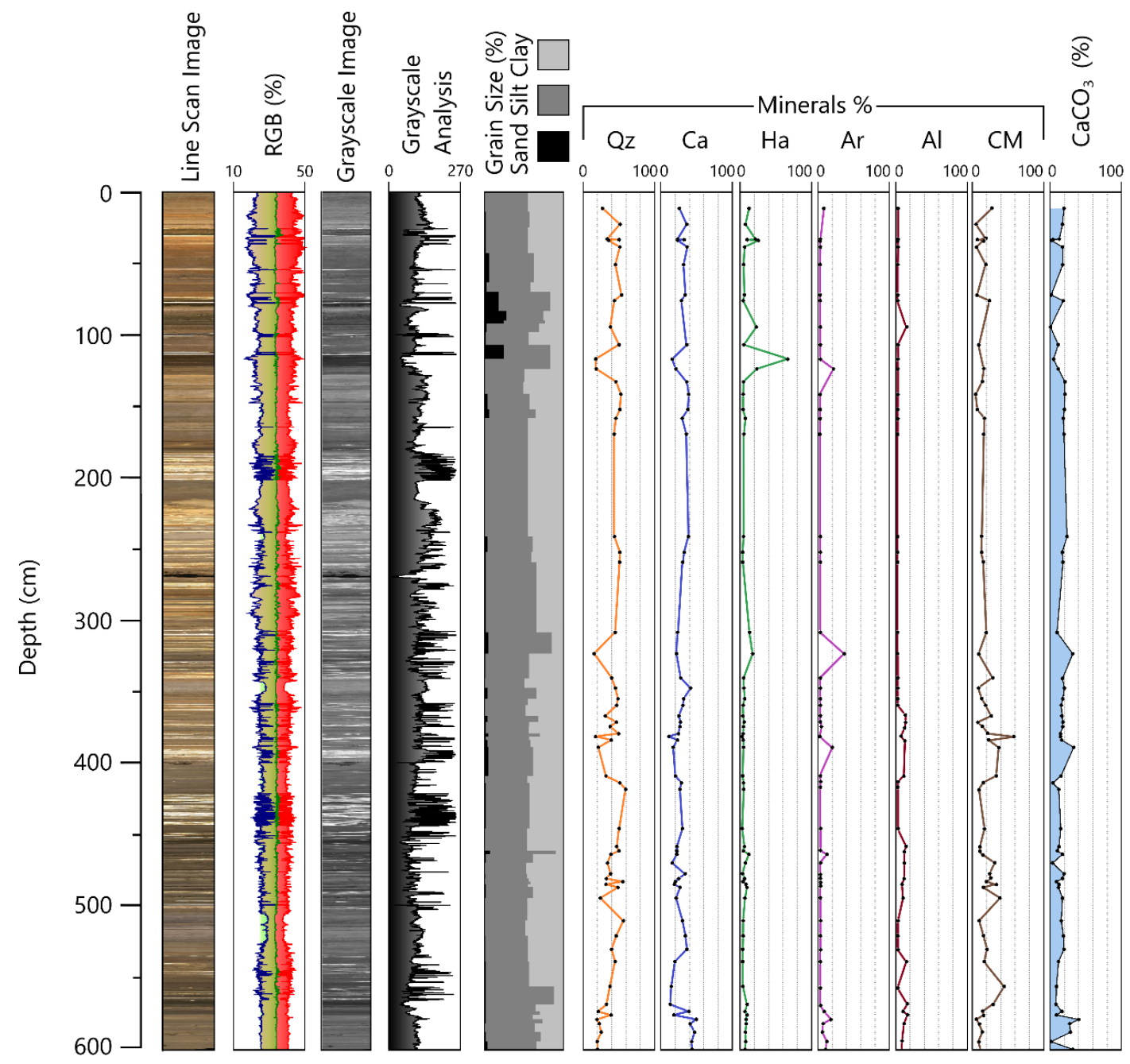

Figure 2. Log profile of Vouliagmeni core presenting (from left to right): Line scan image of the core, RGB (\%) profile, 8-bit grayscale image, grayscale analysis values, grain size distribution, mineralogical composition (\%) (Qz: quartz, Ca: calcite, Ha: halite, Ar: aragonite, Al: albite, CM: clay minerals) and $\mathrm{CaCO}_{3}$ content.

Grain size does not present significant variations in the sediment sequence, with silt and clay fractions ranging from 55 to $70 \%$ and 35 to $50 \%$, respectively (Figure 2). Sand fraction was only recorded in the upper part of the sediment core (50-150 cm) ranging from 1 to $10 \%$ (Figure 2). The mineralogical composition of the non-laminated sections shows high variability, with quartz, calcite, halite, aragonite, albite and clay minerals displaying the highest compound. Quartz and calcite comprise the main mineralogical facies through the sequence and generally follow the same trend (Figure 2). Lower values of both minerals occur in sections $120-140,320-330$ and $450-470 \mathrm{~cm}$. Halite values range from $\sim 0$ to $10 \%$, except for a single sample at $130 \mathrm{~cm}$ with a value of $60 \%$. Aragonite and albite range from $\sim 0$ to $8 \%$ and $\sim 0$ to $7 \%$, respectively, with no significant changes in the sequence. Clay minerals range from $\sim 1$ to $20 \%$ with a mean value of $12 \%$.

The $\mathrm{CaCO}_{3}$ content measured in the non-laminated parts ranges from $\sim 0$ to $45 \%$, with the highest values recorded at 320 and $380 \mathrm{~cm}$ (Figure 2). Carbonate precipitation seems to be constant in the system, as indicated by most measurements conducted on the core, but continuously altering regarding crystallization process. Samples examined for micro and macrofauna remains were all barren, except for five samples at 85, 290, 470, 570 and $590 \mathrm{~cm}$, where minor assemblages of intact juvenile Cerastoderma glaucum shells were recognized and used for radiocarbon dating. 


\subsection{Microstructural Analysis}

\subsubsection{Laminated Sections}

X-ray radiographs were composed for each core segment individually, and the mean HU value for each slice was extracted through SedCT software [86]. Colorized and grayscale images (Figure 3a) generated through the software reflect the interaction between the beam of gamma rays with the sediment and are highly dependable on the alternating density of non-laminated and laminated deposits. Sections with blue-based colors indicate lower HU values and thus lower density, whereas areas with more yellow/red colors indicate sections of more dense material (Figure 3a). HU values range from 400 to 700 for the laminated sequences and from 900 to 1400 for the non-laminated deposits.

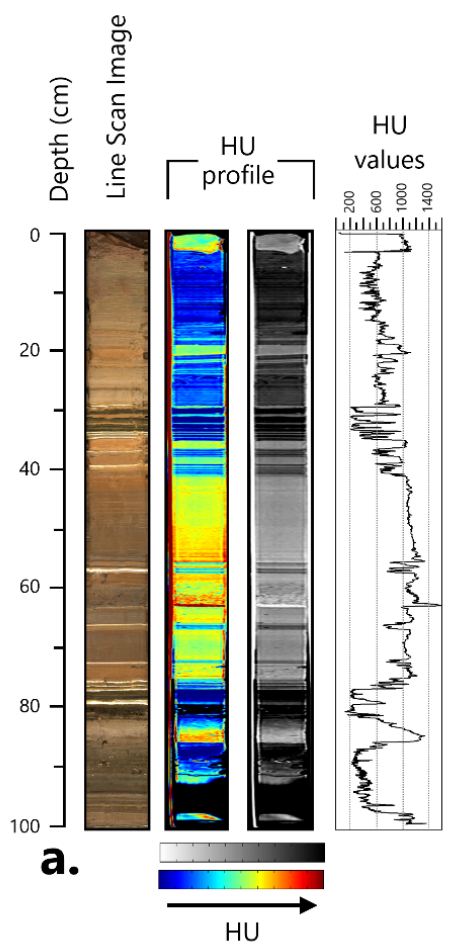

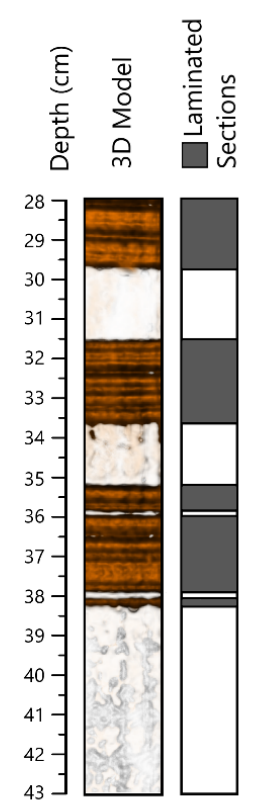

b.

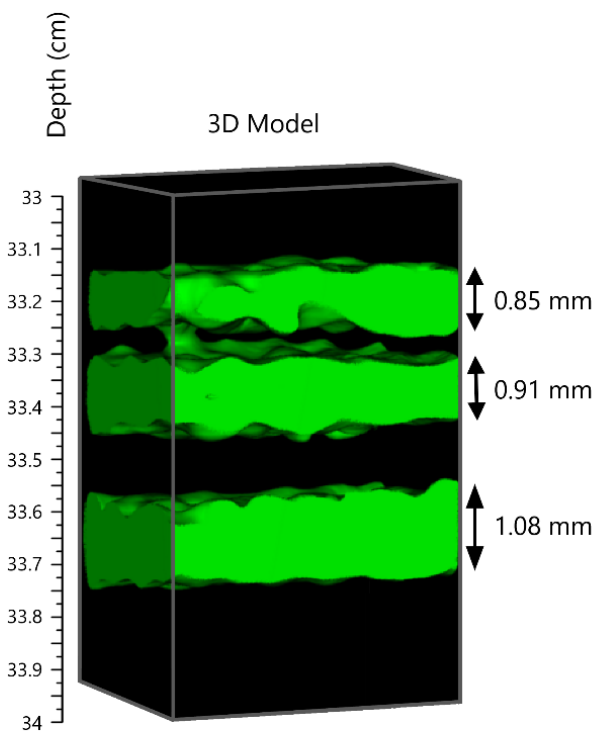

C.

Figure 3. (a) Representative $1 \mathrm{~m}$ core section with line scan image, HU color and grayscale model, and HU absolute values. (b) Varved section with HU values boundaries as they appear during 3D rendering. Laminated sections are presented with brown color and bulk non-laminated sediment with white color. (c) Magnified image of 3 distinct laminations. Calcium-rich laminations are presented with green color.

Since the mineralogical composition does not remain constant in all laminae, minor variations can be expected depending on the HU values; nevertheless, the distinction between the laminated and the non-laminated part can be easily obtained through the 3D model (Figure 3b). A two-scale approach was used for better visualization and distinct laminae counting. In larger-scale images, the mean HU value for all $\mathrm{CaCO}_{3}$-rich deposits was obtained by using INOBITEC medical software; thus, these sections (Figure $3 b$ ) were separated from the rest of the material. Visualization of the annual layers (varves) was enhanced by just focusing on regions of interest (ROI) (Figure 3c). Thickness/counting of each lamination can be then measured through the same software or by extracting 2D images from each section.

The $\mu \mathrm{CT}$ data, when compared to the medical CT models, indicate an estimated error in lamination boundaries of around $0.5 \%$ since the resolution of both methods exceeds the minimum requirements for lamination distinction. The structural or "sphere fitting" thickness model (Figure 4) constructed through CTan plug-in software was compared to the rendered volume, for a more coherent distinction between laminations. 

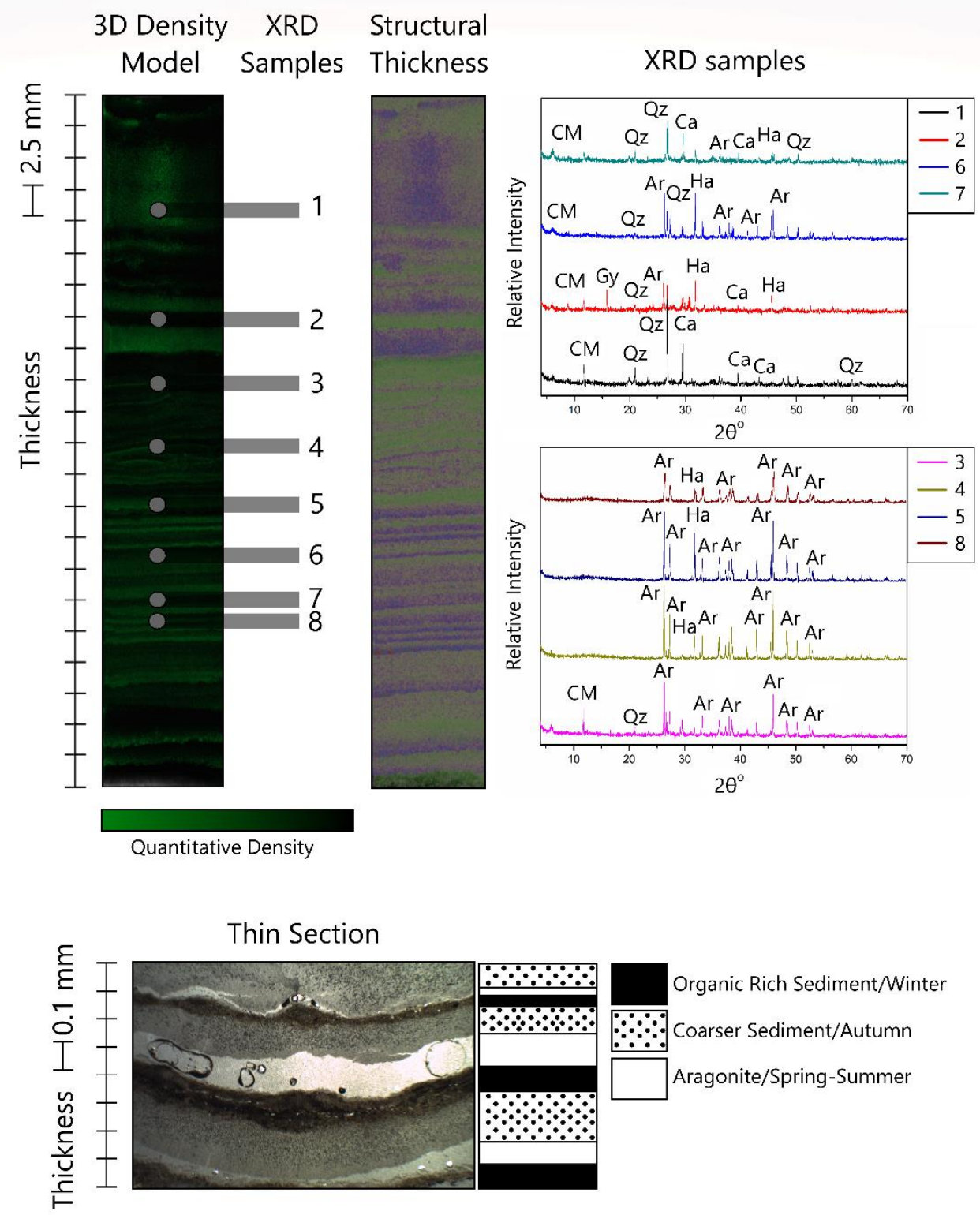

Figure 4. Representative section (core depth: 190-195.5 cm) of $\mu \mathrm{CT}$ analysis presenting the 3D rendered volume and structural thickness model. XRD results of the 8 samples analyzed were selected from white/calcite and brown/bulk laminations. Seasonal sublayers identified through the microscopic analysis are presented with a simplified stratigraphic column.

The varve cycle in Vouliagmeni lake primarily consists of three distinct layers with variance in mineralogical composition, as indicated by the microscopic analysis. White carbonate laminae consist of aragonite and are deposited in dry summer conditions when evaporation in the lake water is high. Precipitation of coarser crystals, in the gray sublayer (Figure 4), is linked to the beginning of runoff events during autumn, reaching the maximum intensity in the dark, organic-rich laminae deposited during winter months. Minerogenic grains like quartz and calcite, mixed with organic residues, are the main components of the dark laminae. Laminae mineralogical composition and absence/presence of laminae are strongly connected to the precipitation/evaporation regime in the lake; thus, the varves of the Lake Vouliagmeni are characterized as endogenic. 


\subsubsection{Non-Laminated Sections}

The nature of the non-laminated section deposition was examined separately through the HU/density model, MS measurements and Mn content (Figure 5a). Six main event deposits/turbidity flows were distinguished (128-136, 139-145, 148-158, 343-352, 492-496, 505-520 cm), interrupting the laminated sections and presenting the highest values of HU, MS and Mn (Figure 5a). High-density sediment sections, like the one occurring at 100-120 cm, were not classified as event deposits, since they did not present any high values of MS (Figure 5a). Turbidite layers that were recognized are not characterized by inverse grading but by a more homogenous distribution of the coarser fraction (Figure 5b).

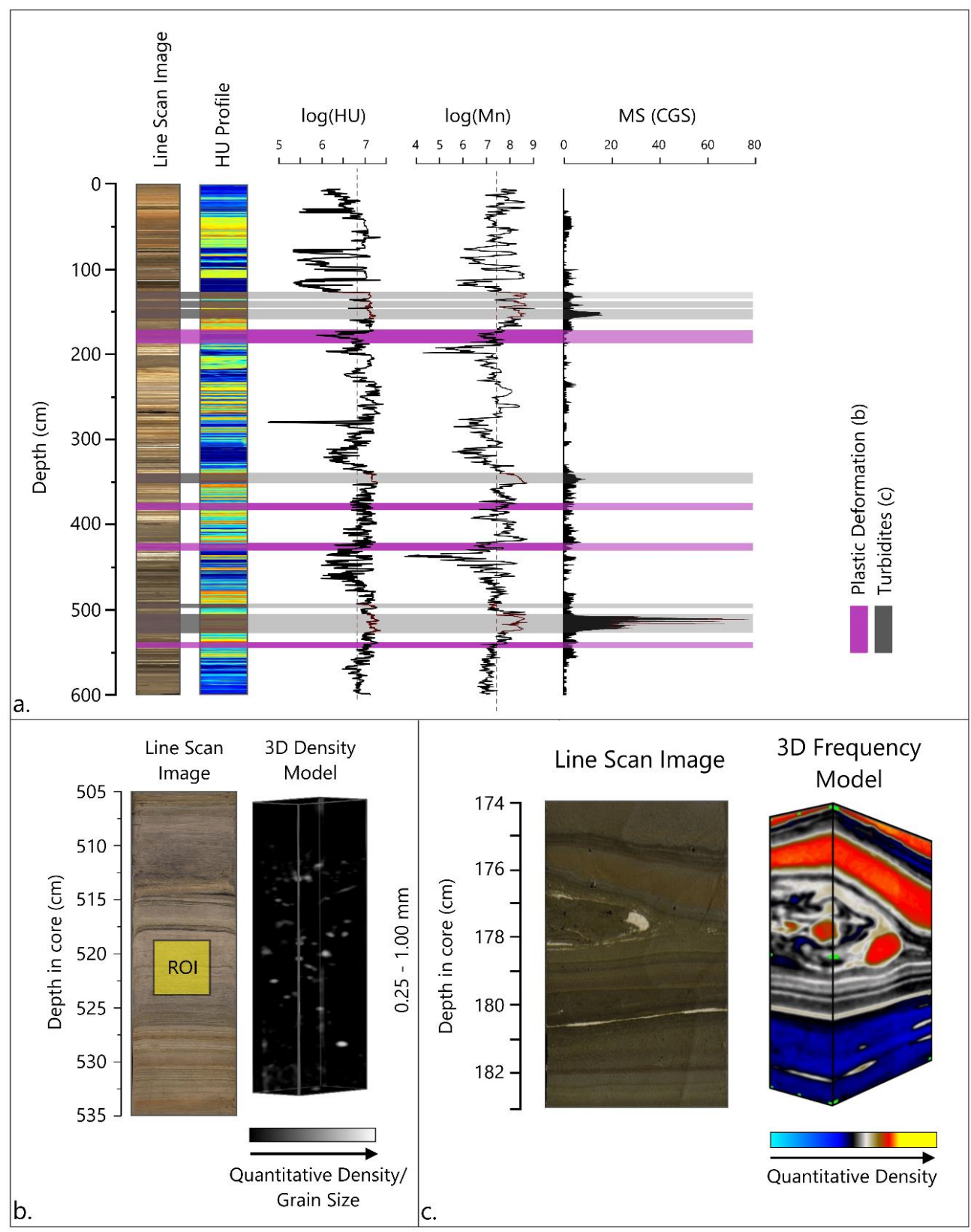

Figure 5. (a) Line scan image and HU colorized model of Vouliagmeni core, with $\log (\mathrm{HU}), \log (\mathrm{Mn})$ and magnetic susceptibility measurements profile. (b) Section of a non-varved sequence, with the compiled 3D grayscale model, presenting homogenous distribution of coarser sediment fractions. (c) Section of disturbed laminated sequence, with the 3D frequency model, showing laminae folding. 
Post-depositional soft-sediment deformation structures (SSDS) were detected in four laminated sections (176-178, 380-381, 436-437, 543-544 cm). Folding (Figure 5c), as well as convolute bedding, were the two main groups of SSDS recognized. Laminae structural characteristics in the deformed sections could still be observed. Folding laminae were observed to be followed by higher density deposits with thickness ranging from 0.4 to $1.3 \mathrm{~cm}$.

\subsection{Hierarchical Clustering}

From the 14 elements measured through XRF scanning, calcium is the dominant one, representing around $45 \%$ of the total counts. Calcium in the lake can derive from limestone weathering in the catchment or through autochthonous precipitation inside the lake. Elements measured with the second $(19.6 \%)$ and third $(10 \%)$ higher abundance were $\mathrm{Fe}$ and $\mathrm{Si}$, respectively. Signals obtained from those elements can be associated with an allochthonous origin from the Flysch formations and the coastal deposits in the study area.

The correlation between elemental concentrations, HU values and MS was expressed through a hierarchical clustering (Pearson correlation distance) heatmap (Figure 6). Three main clusters were exported from the analysis, mirroring different prevailing climatic and in-lake physiochemical conditions. Measured elements were distinguished in Cluster A and Cluster C, with detrital originated elements and carbonate groups composing them, respectively. HU values and MS measurements are expressed in Cluster B and are primarily associated with highly dense material as well as event layers.

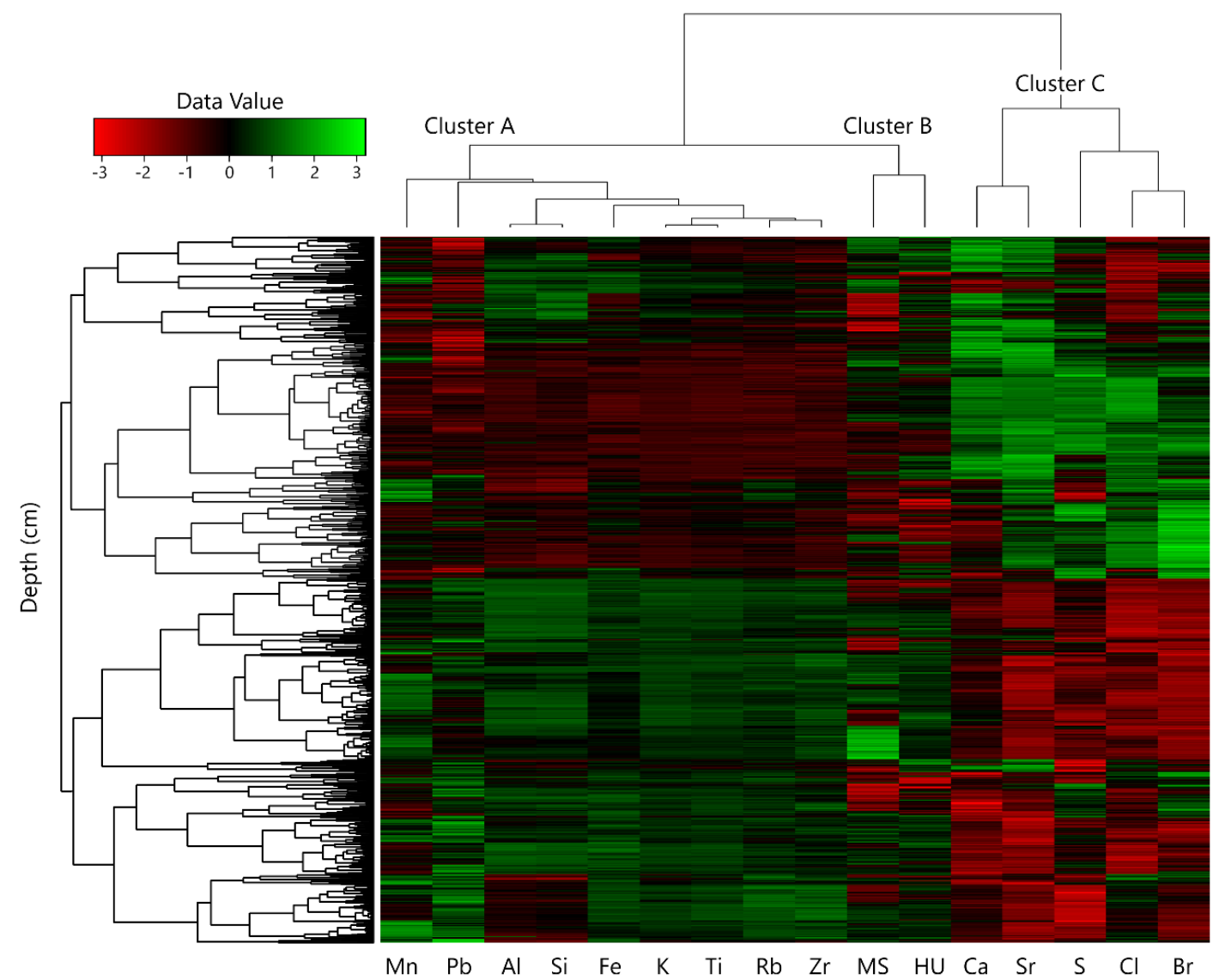

Figure 6. Hierarchical clustering heatmap of Pearson correlation coefficients between non-destructive techniques results for each depth $(\mathrm{cm})$ measured. The 3 main clusters that were exported are presented at the top of the heatmap. 
During XRF scanning, elements intensities are acquired through repeated and continuous counts on the sediment core. The random error that can occur during measurements, combined with the constant radiation used on all core segments that were scanned, does conform to a Poisson distribution [93]. However, in the heatmap (Figure 6), three different analytical methods with variations in radiation and exposure parameters were used; thus, the dataset does not demonstrate a normal/Gaussian distribution. For this reason, $\log$ (base 10) values rather than z-scores were used for each variable.

\subsection{Bayesian Age-Depth Model}

The chronological framework of the core covered approximately the last 12,000 years and was established through Bayesian age-depth modeling, using the R package Rbacon (v.2.3; [94]) and the terrestrial calibration curve IntCal13 [92] (Figure 7). The construction of the age-depth model was based on the 10 radiocarbon dates that were obtained from shells, organic-rich sediment and charcoal (Table 1). The core top age was set to 2018 CE, which was the year of coring. Turbidite layers that were recognized in the sediment sequence were assigned as "slumps" (event deposits), in the Rbacon script. Laminated sequences' accumulation rates were not taken into account in the final age-depth model since it would have been impossible to add anchor dates for all of them.

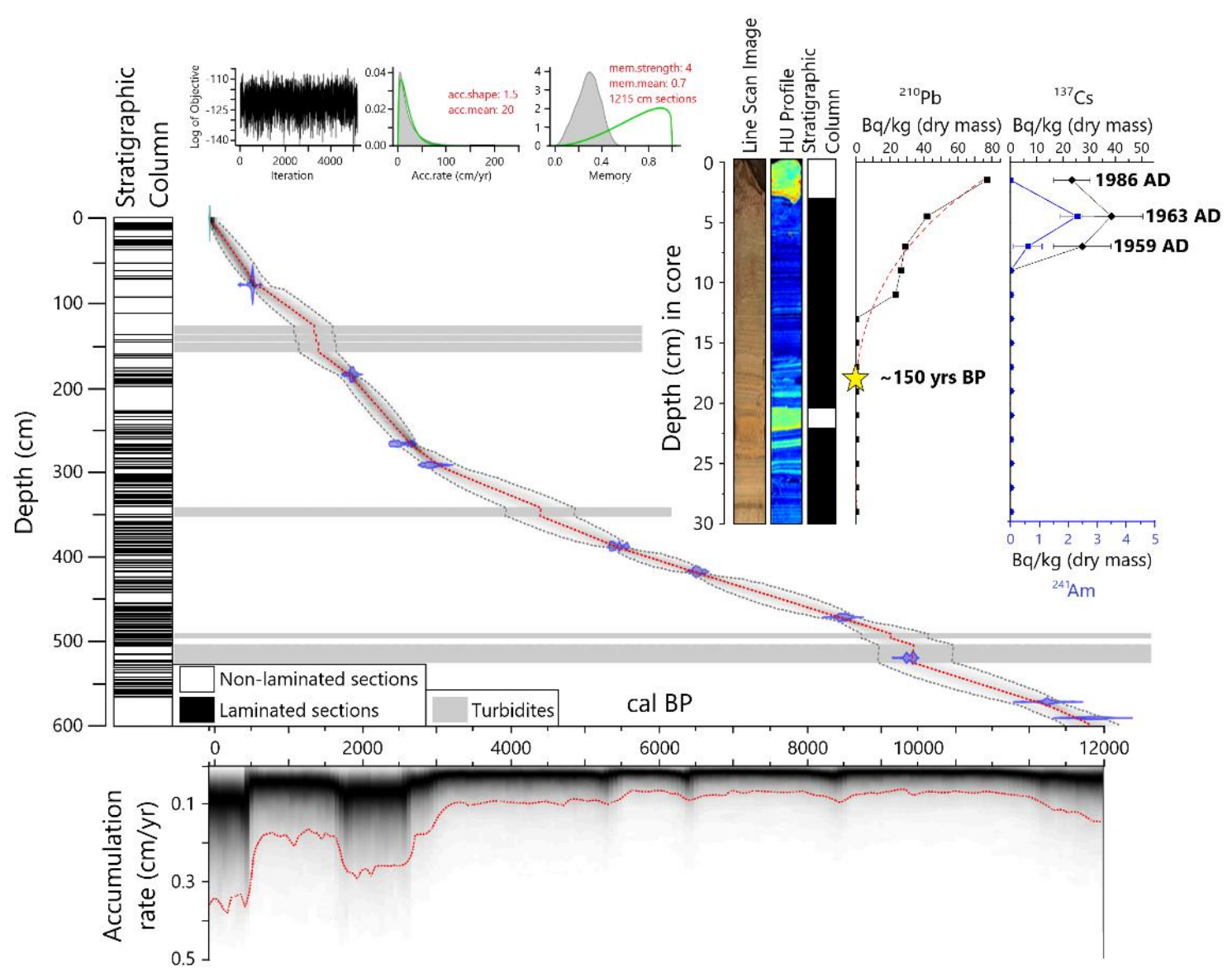

Figure 7. Bayesian age-depth model and accumulation rates constructed using the R package rbacon [94] with defined laminated sections presented to the left. Identified turbidite deposits respond to the gray-colored sections. Radionuclide results are presented on the top right, including ${ }^{210} \mathrm{~Pb},{ }^{137} \mathrm{Cs}$ and ${ }^{241} \mathrm{Am}$ profiles, in comparison with the HU model and the simplified stratigraphy of the sediment sequence (0-30 cm depth). 
Radionuclide measurements were conducted on 14 samples, covering the uppermost $30 \mathrm{~cm}$ of the sediment core. Unsupported ${ }^{210} \mathrm{~Pb}$ inventory was extrapolated according to [95] and by assuming a constant influx of ${ }^{210} \mathrm{~Pb}$ into the system since no event-linked sedimentation was recognized in this section $[96,97]$. The concentration limit was assigned at $17.5 \mathrm{~cm}$ with an age of $\sim 150 \mathrm{yrs}$. Deposition of ${ }^{137} \mathrm{Cs}$ was detected at its maxima at the depths of $1.5,4.5$ and $7.5 \mathrm{~cm}$. The fallout of the Chernobyl accident in $1986 \mathrm{CE}$ was recorded at $1.5 \mathrm{~cm}$ depth, followed by the nuclear weapon tests in the 1960s. The co-presence of ${ }^{241} \mathrm{Am}$ and ${ }^{137} \mathrm{Cs}$ supports the connection between ${ }^{137} \mathrm{Cs}$ peaks and the nuclear tests $[98,99]$. From 4.5 to $7.5 \mathrm{~cm}, 8 \pm 2$ seasonal laminations were measured, responding to 4 years, which is in agreement with the ${ }^{137} \mathrm{Cs}$ chronology.

\section{Discussion}

\subsection{Non-Destructive Proxies}

The comparison of medical CT with $\mu \mathrm{CT}$ scanning reveals that both techniques are an effective and fast way for sediment core internal structure characterization. Laminae distinction, as well as event layers, could easily be determined through the proposed workflow. The main advantage compared to thin-section micromorphology examination is that, during thin section preparation, lamination disturbance and distention could lead to inaccurate measurements of lamination boundaries/thickness [45]. Processing of the acquired data is also much faster compared to thin section preparation and resin impregnation on the sediment samples, which would require much time to cover the whole sediment sequence. However, in the Lake Vouliagmeni sediment core, laminae sublayers could only be detected through microscopic analysis, which leads to the conclusion that the use of both methods is essential for thorough microstructural examination.

Density is a crucial parameter in X-ray interaction with matter [100-103]. Since CT scanners "express" this interaction with HU values, optimizing the output 3D rendered volumes with specific boundaries can provide information on the desired parameter. On the studied core, we used a range of $\mathrm{HU}$ values that would represent the white/aragonite-rich laminations and exclude the brown/black/organic-rich deposits. The principle behind this proposed method is similar to the one used by [104] to distinguish gastropod shells and calculate sediment versus shell percentage on a lagoonal sediment core. The main drawbacks during $\mathrm{CT}$ analysis are that, depending on the lamination thickness, older CT systems may not provide the required resolution to address lamination boundaries. Furthermore, due to the massive data amount produced from even $1 \mathrm{~m}$ of the sediment core from the CT scanner ( 4000 DICOM files), standard personal computers may not be adequate to create the 3D rendered volumes.

Chemical weathering in the lake system is interpreted by variations in $\mathrm{Rb} / \mathrm{Sr}$ ratio [105-109] (Figure 8). During matrix weathering and transport, $\mathrm{Rb}$ is a common substitution of potassium (K) in $\mathrm{K}$-feldspars that comprise the crystal lattice of clay minerals. Alkaline elements like Sr and Ca enter the lake catchment either from an allochthonous source (carbonate weathering) or from autochthonous sedimentation inside the lake in the form of $\mathrm{SrCO}_{3}[110,111]$. Both geochemical proxies present a near symmetrical distribution in the sediment sequence (Figure 8 ), with higher values indicating wet conditions in the study area, triggering extensive erosion and sediment flux in the lake.

In limestone-rich environments, calcium precipitates in the form of $\mathrm{Ca}^{2+}$ and $\mathrm{CO}_{3}{ }^{2-}$ ions, especially under anoxic/hypoxic conditions [112-116]. The solubility of $\mathrm{CaCO}_{3}$ decreases during dry periods, thus forming carbonaceous laminated deposits [117] if lake bottom conditions are favorable. Positive balance between precipitation and evaporation is characterized by higher values of $\mathrm{Ca} / \mathrm{Sr}$ ratio [110] and lamination frequency (number of laminae/cm) in the sediment sequence (Figure 8), with aragonite accumulation occurring during dry seasons. Mn and Fe are positively affected by redox potential in the catchment, with Fe ions precipitating earlier than $\mathrm{Mn}$ ions due to decreased stability. Higher concentrations occur in oxidizing environments [108,118-121] or events in which the lake bottom is re-oxygenated. 
High values of $\mathrm{Zr} / \mathrm{Rb}$ and $\mathrm{Si} / \mathrm{Ti}$ are associated with coarser sediment material and biogenic silica (diatoms) in the sediment sequence [40,122-126], while the clay fraction is mostly represented by allochthonous $\mathrm{Rb}$ accumulation. A correlation between elements with high atomic numbers like $\mathrm{Zr}$ and $\mathrm{HU}$ values has been recorded by [88], at the coarse base of turbidite deposits. The Lake Vouliagmeni sediment sequence is characterized by the dominance of the finer sediment fraction (silt/clay) including quartz and calcite crystals, indicating the dominance of chemical weathering in the catchment.

\subsection{Paleoenvironmental Interpretation}

The Lake Vouliagmeni sediment record displays continuous sedimentary cycles of endogenic varve sedimentation, interrupted by non-laminated deposits (Figure 8). The lake is located in a tectonic, fault-controlled, karstic coastal landscape, and due to the interaction between the lake and the open sea, the distinction between the marine and lacustrine character of the varves is difficult to determine [19]. The occurrence of typically identical varve sections throughout the sediment sequence and the presence of Lithophaga shells at the west coast of the lake [73] verify that the lake always interacted with the Gulf of Corinth. Additionally, the preservation/deposition of varves in the sediment sequence depends on sporadic water column density, stratification and anoxic conditions in the lake bottom that would decrease bioturbation [18].

During the formation of Vouliagmeni lake at the onset of the Holocene period [72], lake water conditions were not favorable for varve preservation until $10800 \mathrm{cal} \mathrm{BP}$ (Figure 8 ). Cluster $C$ dominance in this period reflects high concentrations of $\mathrm{Ca}, \mathrm{Sr}$ and $\mathrm{S}$ in the homogenous sediment. High seismicity rates during the Pleistocene-Holocene transition and the constant uplift of the Perachora peninsula during this period [72] must have been responsible for the laminae folding at $\sim 10,000$ cal BP. Perennial humid conditions, inferred from a Rb/Sr increase, commence from $\sim 10,800$ until $\sim 8000$ cal BP and reach local maxima at $\sim 9000$ and $\sim 9500 \mathrm{cal} \mathrm{BP}$. An increase in water level due to the rising sea level [72] and possible high discharge of the karstic aquifer, suggested by high $\mathrm{Ca} / \mathrm{Sr}$ values [127] during this time, is in agreement with other Eastern Mediterranean studies [128-130]. Two flood turbidites recorded during this time account for the re-oxygenation of the lake bottom water, as indicated by the increase in the $\mathrm{Mn} / \mathrm{Fe}$ ratio. Both turbidite events are mainly associated with Cluster $\mathrm{B}$, which reflects increased MS and HU values and increased precipitation in the area and sediment flux into the lake.

Between 8000 and $7200 \mathrm{cal} \mathrm{BP}$, the absence of varves highlights the positive balance between precipitation and evaporation ratio. Humid climatic conditions that could lead to a decrease in lake water salinity and alternation of water $\mathrm{pH}$ (rise to $\sim 9$ ) combined with possible wind-driven mixing, as shown by a small increase in the $\mathrm{Mn} / \mathrm{Fe}$ ratio [131], preclude stable stratification of the water column. Extensive freshwater inflow into the system could also lead to dislocation of the hypoxic/anoxic layer at the lake bottom, causing oxidation of the bottom surface that could potentially lead to bioturbation. Similar patterns of anoxic zone movement into upper layers have been recorded in the Amvrakikos Gulf [132,133] and Aetoliko lagoon [134] in Western Greece. A transition to an arid phase around 7200-6800 cal BP, as suggested by a low Rb/Sr ratio, has also been recorded in other sites of the Eastern Mediterranean region $[135,136]$. Cluster A, dominant during this phase, expresses arid conditions and is composed of detrital originated elements. Increased lamination frequency during this period is in comparison with the anoxic status indicated by low $\mathrm{Mn} / \mathrm{Fe}$ (Figure 8). Coarser sediment indicated by high $\mathrm{Zr} / \mathrm{Rb}$ and $\mathrm{Si} / \mathrm{Ti}$ (Figure 8) may have accumulated at the lake bottom through a seismic event that also produced the laminae deformation at this point. However, no distinct event deposits were recognized in the sequence. 


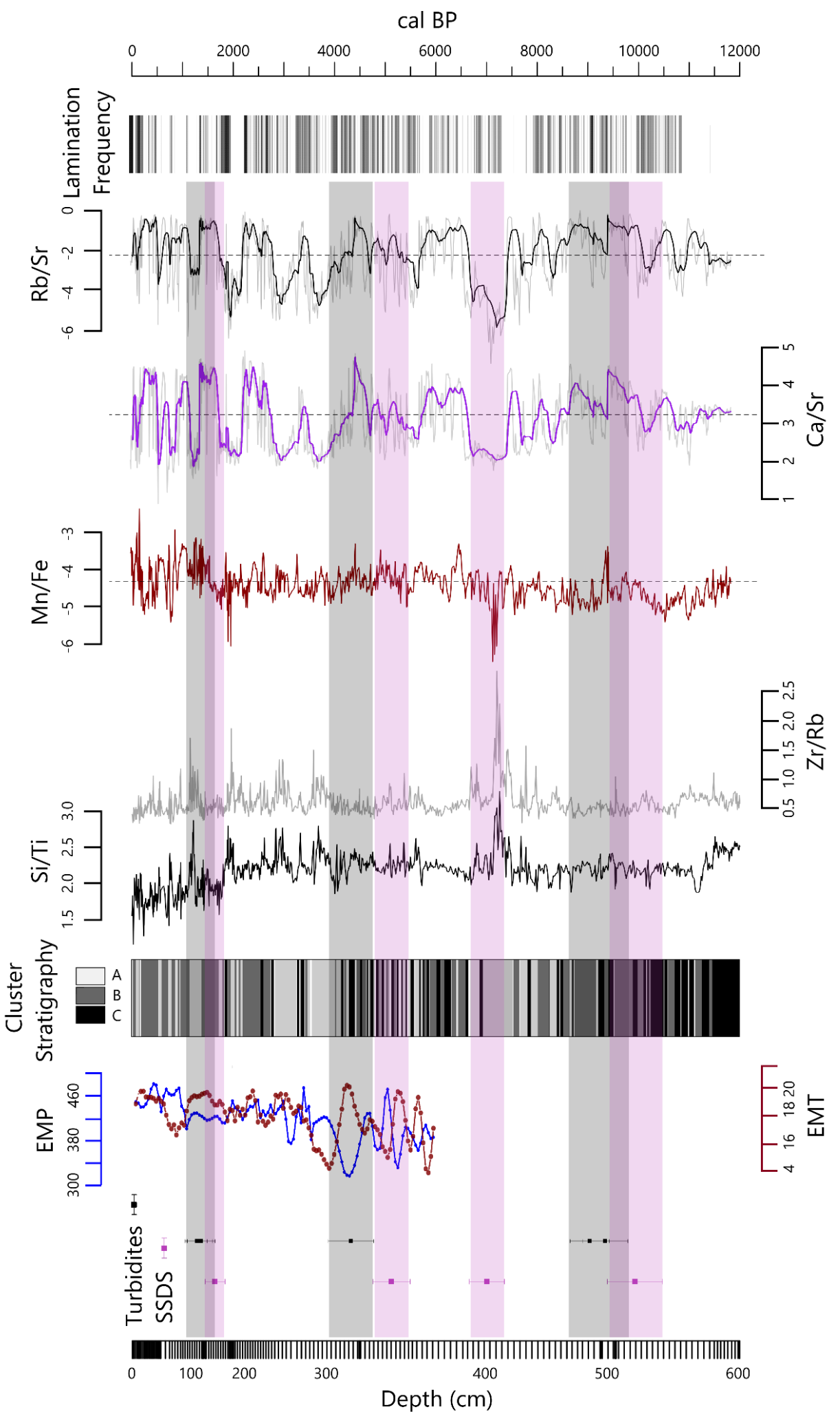

Figure 8. Multi-proxy diagram including geochemical profiles of $\mathrm{Rb} / \mathrm{Sr} \mathrm{Ca} / \mathrm{Sr}, \mathrm{Mn} / \mathrm{Fe}, \mathrm{Zr} / \mathrm{Rb}$ and Si/Ti, lamination frequency as measured through CT analysis, clustering stratigraphy exported through the constructed heatmap, Eastern Mediterranean precipitation and temperature model for mid- to late-Holocene as suggested by [137] and Turbidite deposits, as well as SSDS, recognized in the core. Turbidite deposits and SSDS were assigned with additional $2 \sigma$ error as suggested by the age-depth model. 
From 6500 to $4000 \mathrm{cal} \mathrm{BP}$, the high frequency of laminated deposits is attributed to increased weathering of the limestone-rich catchment and saturation of the lake water with $\mathrm{CaCO}_{3}$. Eastern Mediterranean precipitation and temperature model (EMP and EMT) [137] present their maxima at around $4000 \mathrm{cal} \mathrm{BP}$, reflecting dry and hot phases. In warm summer months, when the lake water temperature increases, $\mathrm{CaCO}_{3}$ becomes more soluble [18] and precipitates in the form of aragonite [117]. In the course of this period, destruction of an early Helladic settlement in the area at around $4300 \mathrm{yrs}$ BP [72] corresponds to the flood turbidite layer recognized around this time. Heavy precipitation combined with the steep geomorphology of the area seem to have been the triggering mechanisms for the hyperpycnal flow [138].

The transition to the late Holocene period ( $3000 \mathrm{cal}$ BP to present) is accompanied by an increase in sedimentation rate into the system, probably caused by extensive urban development $[139,140]$ that led to landscape modifications such as deforestation, agriculture, drainage of water bodies, etc. A dry period recorded from 3600 to $3000 \mathrm{cal}$ BP during the late Bronze age civilization expansion [15,130,141-143] is reflected in Lake Vouliagmeni by a distinct decrease in the $\mathrm{Rb} / \mathrm{Sr}$ ratio. The period after $2000 \mathrm{cal} \mathrm{BP}$ can be characterized as relatively stable compared to the early- and mid-Holocene periods. Lamination frequency presents the highest increase during this time, possibly due to increased eutrophication in the lake system, caused by extensive anthropogenic activity. The rupture of the fault system around $1950 \mathrm{cal} \mathrm{BP}$ is the cause of laminae deformation at this time and the triggering mechanism of the turbidite deposit.

\section{Conclusions}

The Vouliagmeni lake sediment record is formed through a complex interplay between prevailing environmental conditions and in-lake sedimentary mechanisms. Using a multi-proxy approach that included core-logging non-destructive techniques and standard sedimentological analysis, varve formations and sedimentological facies were determined. Varved sections were distinguished from the non-laminated deposits, after applying HU boundaries during 3D reconstruction. Sediment semi-quantitative density, as recorded through CT scanning, was used for event layer recognition as well as soft sediment deformations. Sedimentological processes in the lake can be categorized into three main clusters/facies mirroring variations in climatic conditions and sediment flux. Clusters $\mathrm{A}$ and $\mathrm{B}$ were characterized by non-continuous laminated sediments, during the arid and humid phases, respectively. Cluster C, occurring mostly at the early stage of the lake, reflects homogenous, non-laminated, Ca-rich deposits. The alternation between well-varved and non-varved deposits, combined with the high susceptibility of the area in tectonic calamities, defines Vouliagmeni lake as one of the most promising archives of Greece for the study of paleoenvironmental/paleoclimatic transitions along with the active tectonism of the eastern Gulf of Corinth during the Holocene period.

Author Contributions: Conceptualization P.A. and A.E.; XRF scanning A.E.; CT scanning A.E.; $\mu$ CT scanning K.K. A.E. and XRD analysis E.G. and A.E.; writing-original draft preparation A.E; review and editing, A.E., P.A., I.U., J.S., E.G. and K.K.; sampling and field campaign were supported by A.E., P.A., I.U. and J.S. P.A designed the project. All authors have read and agreed to the published version of the manuscript.

Funding: This research received no external funding.

Acknowledgments: This research is co-financed by Greece and the European Union (European Social Fund- ESF) through the Operational Program "Human Resources Development, Education and Lifelong Learning" in the context of the project "Strengthening Human Resources Research Potential via Doctorate Research" (MIS-5000432), implemented by the State Scholarships Foundation (IK $\curlyvee)$. $\mu$ CT scanning was supported by BIOIMAGING-GR (MIS 5002755) implemented under "Action for Strengthening Research and Innovation Infrastructures" funded by the Operational Programme" Competitiveness, Entrepreneurship and Innovation" (NSRF 2014 2020) and co-financed by Greece and the European Union (European Regional Development Fund). We also kindly thank the University Hospital of Patras for the use of CT scanner, as well as the following colleagues and students for their support during the field work of the project: Petros Zampakis, Epameinondas Ntzanis, Walter Dörfler, Jan Weber, Mathias Bahns, IoannisPrevedouros, Dimitris Bassukas and Evaggelos Tsiotsis.

Conflicts of Interest: The authors declare no conflict of interest. 


\section{References}

1. Willis, K.J. The late Quaternary vegetational history of northwest Greece: I. Lake Gramousti. New Phytol. 1992, 121, 101-117. [CrossRef]

2. Frogley, M.R.; Griffiths, H.I.; Heaton, T.H.E. Historical biogeography and late Quaternary environmental change of Lake Pamvotis, Ioannina (North-western Greece): Evidence from ostracods. J. Biogeogr. 2001, 28, 745-756. [CrossRef]

3. Lawson, I.T.; Al-Omari, S.; Tzedakis, P.C.; Bryant, C.L.; Christanis, K. Lateglacial and Holocene vegetation history at Nisi Fen and the Boras mountains, northern Greece. Holocene 2005, 15, 873-887. [CrossRef]

4. Leng, M.J.; Baneschi, I.; Zanchetta, G.; Jex, C.N.; Wagner, B.; Vogel, H. Late Quaternary palaeoenvironmental reconstruction from Lakes Ohrid and Prespa (Macedonia/Albania border) using stable isotopes. Biogeosciences 2010, 7, 3109-3122. [CrossRef]

5. Ariztegui, D.; Anselmetti, F.S.; Robbiani, J.M.; Bernasconi, S.M.; Brati, E.; Gilli, A.; Lehmann, M.F. Natural and human-induced environmental change in southern Albania for the last 300 years-Constraints from the Lake Butrint sedimentary record. Glob. Planet. Chang. 2010, 71, 183-192. [CrossRef]

6. Francke, A.; Wagner, B.; Leng, M.J.; Rethemeyer, J. A late glacial to holocene record of environmental change from Lake Dojran (Macedonia, Greece). Clim. Past 2013, 9, 481-498. [CrossRef]

7. Roberts, N. The Holocene: An Environmental History; John Wiley \& Sons: New York, NY, USA, 2014.

8. Lacey, J.H.; Francke, A.; Leng, M.J.; Vane, C.H.; Wagner, B. A high-resolution Late Glacial to Holocene record of environmental change in the Mediterranean from Lake Ohrid (Macedonia/Albania). Int. J. Earth Sci. 2015, 104, 1623-1638. [CrossRef]

9. Seguin, J.; Avramidis, P.; Dörfler, W.; Emmanouilidis, A.; Unkel, I. A 2600-year high-resolution climate record from Lake Trichonida (SW Greece). EEG Quat. Sci. J. 2020, 69, 139-160. [CrossRef]

10. Seguin, J.; Avramidis, P.; Haug, A.; Kessler, T.; Schimmelmann, A.; Unkel, I. Reconstruction of palaeoenvironmental variability based on an inter-comparison of four lacustrine archives on the Peloponnese (Greece) for the last 5000 years. EEG Quat. Sci. J. 2020, 69, 165-186. [CrossRef]

11. Gassner, S.; Gobet, E.; Schwörer, C.; van Leeuwen, J.; Vogel, H.; Giagkoulis, T.; Makri, S.; Grosjean, M.; Panajiotidis, S.; Hafner, A.; et al. 20,000 years of interactions between climate, vegetation and land use in Northern Greece. Veg. Hist. Archaeobot. 2020, 29, 75-90. [CrossRef]

12. Jahns, S. The Holocene history of vegetation and settlement at the coastal site of Lake Voulkaria in Acarnania, western Greece. Veg. Hist. Archaeobot. 2005, 14, 55-66. [CrossRef]

13. Kuhnt, T.; Schmiedl, G.; Ehrmann, W.; Hamann, Y.; Andersen, N. Stable isotopic composition of Holocene benthic foraminifers from the Eastern Mediterranean Sea: Past changes in productivity and deep water oxygenation. Palaeogeogr. Palaeoclimatol. Palaeoecol. 2008, 268, 106-115. [CrossRef]

14. Avramidis, P.; Iliopoulos, G.; Nikolaou, K.; Kontopoulos, N.; Koutsodendris, A.; van Wijngaarden, G.J. Holocene sedimentology and coastal geomorphology of Zakynthos Island, Ionian Sea: A history of a divided Mediterranean island. Palaeogeogr. Palaeoclimatol. Palaeoecol. 2017, 487, 340-354. [CrossRef]

15. Norström, E.; Katrantsiotis, C.; Finné, M.; Risberg, J.; Smittenberg, R.H.; Bjursäter, S. Biomarker hydrogen isotope composition $(\delta \mathrm{D})$ as proxy for Holocene hydroclimatic change and seismic activity in SW Peloponnese, Greece. J. Quat. Sci. 2018, 33, 563-574. [CrossRef]

16. Emmanouilidis, A.; Katrantsiotis, C.; Norström, E.; Risberg, J.; Kylander, M.; Sheik, T.A.; Iliopoulos, G.; Avramidis, P. Middle to late Holocene palaeoenvironmental study of Gialova Lagoon, SW Peloponnese, Greece. Quat. Int. 2018, 476, 46-62. [CrossRef]

17. Katrantsiotis, C.; Norström, E.; Smittenberg, R.H.; Finne, M.; Weiberg, E.; Hättestrand, M.; Avramidis, P.; Wastegård, S. Climate changes in the Eastern Mediterranean over the last 5000years and their links to the high-latitude atmospheric patterns and Asian monsoons. Glob. Planet. Chang. 2019, 175, 36-51. [CrossRef]

18. Zolitschka, B.; Francus, P.; Ojala, A.E.K.; Schimmelmann, A. Varves in lake sediments-A review. Quat. Sci. Rev. 2015, 117, 1-41. [CrossRef]

19. Schimmelmann, A.; Lange, C.B.; Schieber, J.; Francus, P.; Ojala, A.E.K.; Zolitschka, B. Varves in marine sediments: A review. Earth Sci. Rev. 2016, 159, 215-246. [CrossRef]

20. Tylmann, W.; Zolitschka, B. Annually laminated lake sediments—Recent progress. Quaternary 2020, 3 , 5. [CrossRef] 
21. Johansson, M.; Saarni, S.; Sorvari, J. Ultra-high-resolution monitoring of the catchment response to changing weather conditions using online sediment trapping. Quaternary 2019, 2, 18. [CrossRef]

22. Salminen, S.; Saarni, S.; Tammelin, M.; Fukumoto, Y.; Saarinen, T. Varve distribution reveals spatiotemporal hypolimnetic hypoxia oscillations during the past 200 years in Lake Lehmilampi, eastern Finland. Quaternary 2019, 2, 20. [CrossRef]

23. Theuerkauf, M.; Engelbrecht, E.; Dräger, N.; Hupfer, M.; Mrotzek, A.; Prager, A.; Scharnweber, T. Using annual resolution pollen analysis to synchronize varve and tree-ring records. Quaternary 2019, 2, 23. [CrossRef]

24. Thys, S.; Van Daele, M.; Praet, N.; Jensen, B.; Van Dyck, T.; Haeussler, P.; Vandekerkhove, E.; Cnudde, V.; De Batist, M. Dropstones in lacustrine sediments as a record of snow avalanches-A validation of the proxy by combining satellite imagery and varve chronology at Kenai Lake (South-Central Alaska). Quaternary 2019, 2, 11. [CrossRef]

25. Żarczyński, M.; Szmańda, J.; Tylmann, W. Grain-size distribution and structural characteristics of varved sediments from Lake Żabińskie (Northeastern Poland). Quaternary 2019, 2, 8. [CrossRef]

26. Vegas-Vilarrúbia, T.; Rull, V.; Trapote, M.D.; Cao, M.; Rosell-Melé, A.; Buchaca, T.; Gomà, J.; López, P.; Sigró, J.; Safont, E.; et al. Modern analogue approach applied to high-resolution varved sediments-A synthesis for Lake Montcortès (Central Pyrenees). Quaternary 2020, 3, 1. [CrossRef]

27. Hughen, K.; Southon, J.; Lehman, S.; Bertrand, C.; Turnbull, J. Updated Cariaco Basin 14 C calibration and activity record for the past 50,000 years. Quat. Sci. Rev. 2006, 25, 3216-3227. [CrossRef]

28. Lauterbach, S.; Brauer, A.; Andersen, N.; Danielopol, D.; Dulski, P.; Huels, M.; Milecka, K.; Namiotko, T.; Obremska, M.; Von Grafenstein, U.; et al. Environmental responses to Lateglacial climatic fluctuations recorded in the sediments of pre-Alpine Lake Mondsee (northeastern Alps). J. Quat. Sci. 2011, 26, $253-267$. [CrossRef]

29. Corella, J.; Valero-Garcés, B.; Vicente-Serrano, S.; Brauer, A.; Benito, G. Three millennia of heavy rainfalls in Western Mediterranean: Frequency, seasonality and atmospheric drivers. Sci. Rep. 2016, 6, 38206. [CrossRef]

30. Schlolaut, G.; Staff, R.; Brauer, A.; Lamb, H.; Marshall, M.; Ramsey, C.; Nakagawa, T. An extended and revised Lake Suigetsu varve chronology from $\sim 50$ to $\sim 10 \mathrm{ka}$ BP based on detailed sediment micro-facies analyses. Quat. Sci. Rev. 2018, 200, 351-366. [CrossRef]

31. Vött, A.; Schriever, A.; Handl, M.; Brücker, H. Holocene Palaeographies of the easter Acheloos River Delta and the lagoon of Etoliko (NW Greece). J. Coast. Res. 2007, 234, 1042-1066. [CrossRef]

32. Haenssler, E.; Nadeau, M.J.; Vött, A.; Unkel, I. Natural and human induced environmental changes preserved in a Holocene sediment sequence from the Etoliko Lagoon, Greece: New evidence from geochemical proxies. Quat. Int. 2013, 308-309, 89-104. [CrossRef]

33. Koutsodendris, A.; Brauer, A.; Zacharias, I.; Putyrskaya, V.; Klemt, E.; Sangiorgi, F.; Pross, J. Ecosystem response to human- and climate-induced environmental stress on an anoxic coastal lagoon (Etoliko, Greece) since 1930 AD. J. Paleolimnol. 2015. [CrossRef]

34. Koutsodendris, A.; Brauer, A.; Reed, J.; Plessen, B.; Friedrich, O.; Hennrich, B.; Zacharias, I.; Pross, J. Climate variability in SE Europe since $1450 \mathrm{AD}$ based on a varved sediment record from Etoliko Lagoon (Western Greece). Quat. Sci. Rev. 2017. [CrossRef]

35. Jansen, F.; Gaast, S.; Koster, B.; Vaars, A. CORTEX, a shipboard XRF-scanner for element analyses in split sediment cores. Mar. Geol. 1998, 151, 143-153. [CrossRef]

36. Tjallingii, R.; Röhl, U.; Koelling, M.; Bickert, T. Influence of the water content on X-ray fluorescence core-scanning measurements in soft marine sediments. Geochem. Geophys. Geosyst. 2007. [CrossRef]

37. Croudace, I.; Rindby, A.; ROTHWELL, R. ITRAX: Description and evaluation of a new multi-function X-ray core scanner. Geol. Soc. Lond. Spec. Publ. 2006, 267, 51-63. [CrossRef]

38. Unkel, I.; Björck, S.; Wohlfarth, B. Deglacial environmental changes on Isla de los Estados (54.4 ${ }^{\circ}$ S), southeastern Tierra del Fuego. Quat. Sci. Rev. 2008, 27, 1541-1554. [CrossRef]

39. Heimhoffer, U.; Ariztegui, D.; Lenniger, M.; Hesselbo, S.P.; Martill, D.M.; Rios-Netto, A. Decipering the depositional environment of the laminated Crato fossil beds (Early Cretaceous, Araripe Basin, North-eastern Brazil). Sedimentology 2010, 57, 677-694. [CrossRef]

40. Kylander, M.E.; Ampel, L.; Wohlfarth, B.; Veres, D. High-resolution X-ray fluorescence core scanning analysis of Les Echets (France) sedimentary sequence: New insights from chemical proxies. J. Quat. Sci. 2011, 26, 109-117. [CrossRef] 
41. Deplazes, G.; Meckler, A.N.; Peterson, L.C.; Hamann, Y.; Aeschlimann, B.; Gunther, D.; Martinez-Garcia, A.; Haug, G. Fingerprint of tropical climate variability and sea level in sediments of the Cariaco Basin during the last glacial period. Sedimentology 2019, 66, 1967-1988. [CrossRef]

42. Ketcham, R.; Carlson, W. Acquisition, optimization and interpretation of X-ray computed tomographic imagery: Applications to the geosciences. Comput. Geosci. 2001, 27, 381-400. [CrossRef]

43. Rosenberg, R.; Davey, E.; Gunnarsson, J.; Norling, K.; Frank, M. Application of computer-aided tomography to visualize and quantify biogenic structures in marine sediment. Mar. Ecol. Prog. Ser. 2007. [CrossRef]

44. St-Onge, G.; Long, B. CAT-scan analysis of sedimentary sequences: An ultrahigh-resolution paleoclimatic tool. Eng. Geol. 2008. [CrossRef]

45. Bendle, J.; Palmer, A.; Carr, S. A comparison of micro-CT and thin section analysis of Lateglacial glaciolacustrine varves from Glen Roy, Scotland. Quat. Sci. Rev. 2015. [CrossRef]

46. Vandorpe, T.; Collart, T.; Cnudde, V.; Lebreiro, S.; Hernández-Molina, F.J.; Alonso, B.; Mena, A.; Antón, L.; Van Rooij, D. Quantitative characterisation of contourite deposits using medical CT. Mar. Geol. 2019, 417, 106003. [CrossRef]

47. Tanaka, A.; Nakano, T.; Ikehara, K. X-ray computerized tomography analysis and density estimation using a sediment core from the Challenger Mound area in the Porcupine Seabight, off Western Ireland. Earth Planets Sp. 2011, 63, 103-110. [CrossRef]

48. Polacci, M.; Baker, D.; Mancini, L.; Tromba, G.; Zanini, F. Three-dimensional investigation of volcanic textures by X-ray microtomography and implications for conduit processes. Geophys. Res. Lett. 2006. [CrossRef]

49. Sleutel, S.; Cnudde, V.; Masschaele, B.; Vlassenbroek, J.; Dierick, M.; Hoorebeke, L.; Jacobs, P.; De Neve, S. Comparison of different nano- and micro-focus X-ray computed tomography set-ups for the visualization of the soil microstructure and soil organic matter. Comput. Geosci. 2008, 34, 931-938. [CrossRef]

50. Dewanckele, J.; Cnudde, V.; Boone, M.; Loo, D.; Van Witte, Y.; De Pieters, K.; Vlassenbroeck, J.; Dierick, M.; Masschaele, B.; Hoorebeke, L.; et al. Integration of X-ray micro tomography and fluorescence for applications on natural building stones. J. Phys. Conf. Ser. 2009, 186, 12082. [CrossRef]

51. Sok, R.; Varslot, T.; Ghous, A.; Latham, S.; Sheppard, A.; Knackstedt, M. Pore scale characterization of carbonates at multiple scales: Integration of micro-CT, BSEM, and FIBSEM. Petrophysics 2010, 51, 6.

52. Rozenbaum, O. 3-D characterization of weathered building limestones by high resolution synchrotron X-ray microtomography. Sci. Total Environ. 2011, 409, 1959-1966. [CrossRef] [PubMed]

53. Bouckaert, L.; Sleutel, S.; Denis, V.; Brabant, L.; Cnudde, V.; Hoorebeke, L.; De Neve, S. Carbon mineralisation and pore size classes in undisturbed soil cores. Soil Res. 2013, 51, 14. [CrossRef]

54. Thomson, J.; Croudace, I.W.; Rothwell, R.G. A geochemical application of the ITRAX scanner to a sediment core containing eastern Mediterranean sapropel units. Geol. Soc. Spec. Publ. 2006, 267, 65-77. [CrossRef]

55. Emmanouilidis, A.; Messaris, G.; Ntzanis, E.; Zampakis, P.; Avramidis, P. Microstructural and facies identification through X-ray computed tomography (CT) on annually laminated sediments. Geol. Min. Ecol. Manag. 2019, 19. [CrossRef]

56. Woessner, J.; Danciu, L.; Giardini, D.; Crowley, H.; Cotton, F.; Grünthal, G.; Valensise, G.; Arvidsson, R.; Basili, R.; Demircioglu, M.B.; et al. The 2013 European seismic hazard model. Bull. Earthq. Eng. 2015, 13, 3553-3596. [CrossRef]

57. Clarke, P.; Davies, R.; England, P.; Parsons, B.; Billiris, H.; Paradissis, D.; Veis, G.; Cross, P.A.; Denys, P.; Ashkenazi, V.; et al. Crustal strain in Central Greece from repeated GPS measurements in the interval 1989-1997. Geophys. J. Int. 1998, 135, 195-214. [CrossRef]

58. Bernard, P.; Lyon-Caen, H.; Briole, P.; Deschamps, A.; Boudin, F.; Makropoulos, K.; Papadimitriou, P.; Lemeille, F.; Patau, G.; Billiris, H.; et al. Seismicity, deformation and seismic hazard in the western rift of Corinth: New insights from the Corinth Rift Laboratory (CRL). Tectonophysics 2006, 426, 7-30. [CrossRef]

59. Papadopoulos, G. Tsunami hazard in the eastern Mediterranean: Strong earthquakes and Tsunamis in the Corinth Gulf, Central Greece. Nat. Hazards 2003, 29, 437-464. [CrossRef]

60. Papathoma-Köhle, M.; Dominey-Howes, D. Tsunami vulnerability assessment and its implications for coastal hazard analysis and disaster management planning, Gulf of Corinth, Greece. Nat. Hazards Earth Syst. Sci. 2003. [CrossRef]

61. McNeill, L.C.; Shillington, D.J.; Carter, G.D.O.; Everest, J.D.; Gawthorpe, R.L.; Miller, C.; Phillips, M.P.; Collier, R.E.L.; Cvetkoska, A.; De Gelder, G.; et al. High-resolution record reveals climate-driven environmental and sedimentary changes in an active rift. Sci. Rep. 2019, 9, 3116. [CrossRef] 
62. Kontopoulos, N.; Avramidis, P. A late Holocene record of environmental changes from the Aliki lagoon, Egion, North Peloponnesus, Greece. Quat. Int. 2003, 111, 75-90. [CrossRef]

63. Hadler, H.; Vött, A.; Koster, B.; Mathes-Schmidt, M.; Mattern, T.; Ntageretzis, A.; Reicherter, K.; Willershäuser, T. Multiple late-Holocene tsunami landfall in the eastern Gulf of Corinth recorded in the palaeotsunami geo-archive at Lechaion, harbour of ancient Corinth (Peloponnese, Greece). Z. Geomorphol. 2013. [CrossRef]

64. Kolaiti, E.; Papadopoulos, G.; Vacchi, M.; Triantafyllou, I.; Mourtzas, N. Palaeoenvironmental evolution of the ancient harbor of Lechaion (Corith Gulf, Greece): Were changes driven by human impacts and gradual coastal processes or catastrophic tsunamis? Mar. Geol. 2017. [CrossRef]

65. Vött, A.; Hadler, H.; Koster, B.; Mathes-Schmidt, M.; Röbke, B.; Willershäuser, T.; Reicherter, K. Returning to the facts: Response to the refusal of tsunami traces in the ancient harbour of Lechaion (Gulf of Corinth, Greece) by 'non-catastrophists' - Reaffirmed evidence of harbour destruction by historical earthquakes and tsunamis in AD 69-79 and the 6th cent. AD and a preceding pre-historical event in the early 8th Cent. BC. Z. Geomorphol. 2017. [CrossRef]

66. Emmanouilidis, A.; Unkel, I.; Triantaphyllou, M.; Avramidis, P. Late-Holocene coastal depositional environments and climate changes in the Gulf of Corinth, Greece. Holocene 2020, 30, 77-89. [CrossRef]

67. Heezen, B.C.; Ewing, M.; Johnson, G.L. The Gulf of Corinth floor. Deep Res. Oceanogr. Abstr. 1966, 13, 381-411. [CrossRef]

68. Papatheodorou, G.; Ferentinos, G. Submarine and coastal sediment failure triggered by the 1995, M(s) =6.1 R Aegion earthquake, Gulf of Corinth, Greece. Mar. Geol. 1997, 137, 287-304. [CrossRef]

69. Stefatos, A.; Charalampakis, M.; Papatheodorou, G.; Ferentinos, G. Tsunamigenic sources in an active European half-graben (Gulf of Corinth, Central Greece). Mar. Geol. 2006, 232, 35-47. [CrossRef]

70. Lykousis, V.; Sakellariou, D.; Moretti, I.; Kaberi, H. Late Quaternary basin evolution of the Gulf of Corinth: Sequence stratigraphy, sedimentation, fault-slip and subsidence rates. Tectonophysics 2007, 440, $29-51$. [CrossRef]

71. Tinti, S.; Zaniboni, F.; Armigliato, A.; Pagnoni, G.; Gallazzi, S.; Manucci, A.; Brizuela, B.; Bressan, L.; Tonini, R. Tsunamigenic landslides in the Western Corinth Gulf: Numerical scenarios. In Submarine Mass Movements and Their Consequences; Springer: Dordrecht, The Netherland, 2007; pp. 405-414.

72. Gaki-papanastassiou, K.; Papanastassiou, D.; Maroukian, H. Recent uplift rates at Perachora Peninsula, East Gulf of Corinth, Greece, based on geomorphological—archaeological evidence and radiocarbon dates. Hell. J. Geosci. 2007, 42, 45-56.

73. Stiros, S.C. Palaeogeographic reconstruction of the Heraion-Vouliagmeni Lake Coast since early Helladic times. Annu. Brit. Sch. Ath. Cent. 1995, 90, 17-21. [CrossRef]

74. Maroukian, H.; Gaki-Papanastassiou, K.; Karymbalis, E.; Vouvalidis, K.; Pavlopoulos, K.; Papanastassiou, D.; Albanakis, K. Morphotectonic control on drainage network evolution in the Perachora Peninsula, Greece. Geomorphology 2008, 102, 81-92. [CrossRef]

75. Vardala, T.; Nicolaidou, A. On the recent and fossil malacofauna of "Vouliagmeni Lake", Perachora (Korinthiakos Gulf, Greece). Boll. Malacol. 2007, 43, 62-70.

76. Bassukas, D.; Emmanouilidis, A.; Panagiotaras, D.; Avramidis, P. Sedimentological and geochemical evaluation of Vouliagmeni lake sediments, Perachora, Peninsula, Corinth, Greece. Geol. Min. Ecol. Manag. 2019, 19. [CrossRef]

77. Celet, P.; Clément, B.; Ferrière, J. La zone béotienneen Grèce: Implications paléogéographiques et structurales. Ecl. Geol. Helv. 1976, 69, 577-599.

78. Nixon, C.; McNeill, L.C.; Bull, J.M.; Bell, R.E.; Gawthorpe, R.L.; Henstock, T.J.; Christodoulou, D.; Ford, M.; Taylor, B.; Sakellariou, D.; et al. Rapid spatiotemporal variations in rift structure during development of the Corinth Rift, central Greece. Tectonics 2016, 35, 1225-1248. [CrossRef]

79. Mingram, J.; Negendank, J.F.W.; Brauer, A.; Berger, D.; Hendrich, A.; Köhler, M.; Usinger, H. Long cores from small lakes-Recovering up to $100 \mathrm{~m}$-long lake sediment sequences with a high precision rod-operated piston corer (Usinger-corer). J. Paleolimnol. 2007, 37, 517-528. [CrossRef]

80. Folk, R.L.; Ward, W.C. A study in the significance of grain-size parameters. J. Sed. Petr. 1957, $27,3-26$. [CrossRef]

81. Muller, G.; Gastner, M. The 'karbonat e bombe', a simple device for the determination of carbonate content in sediments, soils and other materials. Neus. Jahr. Miner. 1971, 10, 466-469. 
82. Jones, G.A.; Kateris, P. Avacuum-gasometric technique for rapid and precise analysis of calcium carbonate in sediments and soils. J. Sed. Petr. 1983, 53, 655-660. [CrossRef]

83. Brindley, G.W.; Brown, G. X-ray diffraction procedures for clay mineral identification. In Crystal Structures of Clay Minerals and Their X-ray Identification; Brindley, G.W., Brown, G., Eds.; Miner. Soc.: London, UK, 1980; pp. 305-356.

84. Rollinson, H. Using Geochemical Data: Evaluation, Presentation, Interpretation; Routledge: London, UK, 1993.

85. Weltje, G.J.; Tjallingii, R. Calibration of XRF core scanners for quantitative geochemical logging of sediment cores: Theory and application. Earth Planet. Sci. Lett. 2008, 274, 423-438. [CrossRef]

86. Reilly, B.; Stoner, J.; Wiest, J. SedCT: MATLAB TM tools for standardized and quantitative processing of sediment core computed tomography (CT) data collected using a medical CT scanner. Geochem. Geophys. Geosyst. 2017. [CrossRef]

87. Weber, M.; Korff, L.; Kuhn, G.; Pfeiffer, M.; Korff, B.; Thurow, J.W.; Ricken, W. BMPix and Peak tools: New methods for automated laminae recognition and counting - Application to glacial varves from Antarctic marine sediment. Geochem. Geophys. Geosyst. 2010, 11, 1-18. [CrossRef]

88. Vandekerkhove, E.; Van Daele, M.; Praet, N.; Cnudde, V.; Haeussler, P.J.; De Batist, M. Flood-triggered versus earthquake-triggered turbidites: A sedimentological stdy in clastic lake sediments (Eklutna Lake, Alaska). Sedimentology 2020, 67, 364-389. [CrossRef]

89. Boes, E.; Van Daele, M.; Moernaut, J.; Schmidt, S.; Jensen, B.J.L.; Praet, N.; Kaufman, D.; Haeussler, P.; Loso, M.G.; De Batist, M. Varve formation during the past three centuries in three large proglacial lakes in south-central Alaska. GSA Bull. 2017, 130, 757-774. [CrossRef]

90. Praet, N.; Van Daele, M.; Collart, T.; Moernaut, J.; Vandekerkhove, E.; Kempf, P.; Haeussler, P.J.; De Batist, M. Turbidite stratigraphy in proglacial lakes: Deciphering trigger mechanisms using a statistical approach. Sedimentology 2020, 67, 2332-2359. [CrossRef]

91. Campos, C.; Beck, C.; Crouzet, C.; Carrillo, E.; Van Welden, A.; Tripsanas, E. Late quaternary paleoseismic sedimentary archive from deep central gulf of corinth: Time distribution of inferred earthquake-induced layers. Ann. Geophys 2013. [CrossRef]

92. Reimer, P.; Bard, E.; Bayliss, A.; Beck, J.; Blackwell, P.; Ramsey, C.; Buck, C.; Cheng, H.; Edwards, R.; Friedrich, M.; et al. IntCal13 and MARINE13 radiocarbon age calibration curves 0-50,000 years Cal BP. Radiocarbon 2013, 55, 1869-1887. [CrossRef]

93. Gill, R. Modern Analytical Geochemistry; Longman: London, UK, 1997.

94. Blaauw, M.; Christen, J. Flexible paleoclimate age-depth models using an autoregressive gamma process. Bayesian Anal. 2011, 6, 457-474.

95. Appleby, P.G. Chronostratigraphic Techniques in Recent Sediments BT-Tracking Environmental Change Using Lake Sediments: Basin Analysis, Coring, and Chronological Techniques; Last, W.M., Smol, J.P., Eds.; Springer: Dordrecht, The Netherlands, 2001; pp. 171-203.

96. Arnaud, F.; Lignier, V.; Revel, M.; Desmet, M.; Beck, C.; Pourchet, M.; Charlet, F.; Trentesaux, A.; Tribovillard, N. Flood and earthquake disturbance of ${ }^{210} \mathrm{~Pb}$ geochronology (lake Anterne, NW Alps). Terra Nova 2002, 14, 225-232. [CrossRef]

97. Arnaud, F.; Magand, O.; Chapron, E.; Bertrand, S.; Boes, X.; Charlet, F.; Melieres, M.-A. Radionuclide dating $\left({ }^{210} \mathrm{~Pb},{ }^{137} \mathrm{Cs},{ }^{241} \mathrm{Am}\right)$ of recent lake sediments in a highly geodynamic setting (Lakes Puyehue and Icalma-Chilean Lake District). Sci. Total Environ. 2006, 366, 837-850. [CrossRef]

98. Appleby, P.G.; Richardson, N.; Nolan, P.J. Am-241 dating of lake sediments. Hydrobiologia 1991, $214,35-42$. [CrossRef]

99. Putyrskaya, V.; Klemt, E.; Röllin, S.; Corcho-Alvarado, J.A.; Sahli, H. Dating of recent sediments from Lago Maggiore and Lago di Lugano (Switzerland/Italy) using 137Cs and 210Pb. J. Environ. Radioact. 2020. [CrossRef] [PubMed]

100. Mees, F.; Rudy, S.; Van Geet, M.; Jacobs, P. Applications of X-ray Computed Tomography in the Geosciences; Special Publications; Geological Society: London, UK, 2003. [CrossRef]

101. Carlson, W. Three-dimensional imaging of earth and planetary materials. Earth Planet. Sci. Lett. 2006, 249, 133-147. [CrossRef]

102. Davis, G.; Evershed, A.; Elliott, J.; Mills, D. Quantitative X-ray microtomography with a conventional source. Dev. X-ray Tomogr. 2010. [CrossRef] 
103. Duliu, O. Computer axial tomography in geosciences: An overview. Earth Sci. Rev. 1999, 48, $265-281$. [CrossRef]

104. Emmanouilidis, A.; Messaris, G.; Ntzanis, E.; Zampakis, P.; Prevedouros, I.; Bassukas, D.A.; Avramidis, P. CT scanning, X-ray fluorescence: Non-destructive techniques for the identification of sedimentary facies and structures. Rev. Micropaleontol. 2020. [CrossRef]

105. Chen, J.; Chen, Y.; Liu, L.; Ji, J.; Balsam, W.; Sun, Y.; Lu, H. Zr/Rb ratio in the Chinese loess sequences and its implication for changes in the East Asian winter monsoon strength. Geochim. Cosmochim. Acta 2006, 70, 1471-1482. [CrossRef]

106. Jin, Z.D.; Cao, J.; Wu, J.; Wang, S. A Rb/Sr record of catchment weathering response to Holocene climate change in Inner Mongolia. Earth Surf. Process. Landf. 2006, 31, 285-291. [CrossRef]

107. Xu, H.; Liu, B.; Wu, F. Spatial and temporal variations of $\mathrm{Rb} / \mathrm{Sr}$ ratios of the bulk surface sediments in Lake Qinghai. Geochem. Trans. 2010, 11, 3. [CrossRef]

108. Heymann, C.; Nelle, O.; Dörfler, W.; Zagana, E.; Nowaczyk, N.; Xue, J.; Unkel, I. Late glacial to mid-Holocene palaeoclimate development of Southern Greece inferred from the sediment sequence of Lake Stymphalia (NE-Peloponnese). Quat. Int. 2013, 302, 42-60. [CrossRef]

109. Seguin, J.; Bintliff, J.L.; Grootes, P.M.; Bauersachs, T.; Dörfler, W.; Heymann, C.; Manning, S.W.; Müller, S.; Nadeau, M.J.; Nelle, O.; et al. 2500 years of anthropogenic and climatic landscape transformation in the Stymphalia polje, Greece. Quat. Sci. Rev. 2019, 213, 133-154. [CrossRef]

110. Cohen, A.S. Paleolimnology: The Histroy and Evolution of Lake Systems; Oxford University Press: New York, NY, USA, 2003; p. 528.

111. Koinig, K.A.; Shotyk, W.; Lotter, A.F.; Ohlendorf, C.; Sturm, M. 9000 Years of geochemical evolution of lithogenic major and trace elements in the sediment of an alpine lake-The role of climate, vegetation, and land-use history. J. Paleolimnol. 2003, 30, 307-320. [CrossRef]

112. Bencini, A.; Turi, A. Mn-distribution in the Mesozoic carbonate rocks from Lima Valley, North Apennines. J. Sed. Petrol. 1974, 44, 774-782.

113. Bolton, B.R.; Frakes, L.A. Geology and genesis of manganese oolite, Chiatura, Georgia, U.S.S.R. Geol. Soc. Am. Bull. 1985, 96, 1398-1406. [CrossRef]

114. Jenkyns, H. The early Toarcian (Jurassic) anoxic event: Stratigraphic, sedimentary, and geochemical evidence. Am. J. Sci. 1988, 288, 101-151. [CrossRef]

115. Jenkyns, H.; Géczy, B.; Marshall, J. Jurassic manganese carbonates of central Europe and the early Toarcian Anoxic Event. J. Geol. 1991. [CrossRef]

116. Frakes, L.A.; Bolton, B.R. Effects of ocean chemistry, sea level and climate on the formation of primary sedimentary manganese ore deposits. Econ. Geol. 1992, 84, 2267-2285. [CrossRef]

117. Dean, W.E.; Megard, R.O. Environment of deposition of CaCO3 in Elk Lake, Minnesota. In Elk Lake, Minnesota: Evidence for Rapid Climate Change in the North-Central United States; Bradbury, J.P., Dean, W.E., Eds.; Geological Society of America: Boulder, CO, USA, 1993; Volume 276, p. 97.

118. Canon, W.F.; Force, E.R. Potential for High-Grade Shallow Marine Manganese Deposits in North America, in Unconventional Mineral Deposits; Shanks, W.C., Ed.; Society of Mining Engineers: New York, NY, USA, 1983; pp. 175-189.

119. Frakes, L.A.; Bolton, B.R. Origin of manganese giants: Sea-level change and anoxic-oxic history. Geology 1984, 12, 83-86. [CrossRef]

120. Force, E.R.; Canon, W.F. Depositional model for shallow marine manganese deposits around black shale basins. Econ. Geol. 1988, 81, 93-117. [CrossRef]

121. Davison, W. Iron and manganese in lakes. Earth Sci. Rev. 1993, 34, 119-163. [CrossRef]

122. Dypvik, H.; Harris, N. Geochemical facies analysis of fine-grained siliciclastics using $\mathrm{Th} / \mathrm{U}, \mathrm{Zr} / \mathrm{Rb}$ and $(\mathrm{Zr}+\mathrm{Rb}) / \mathrm{Sr}$ ratios. Chem. Geol. 2001, 181, 131-146. [CrossRef]

123. Cuven, S.; Francus, P.; Lamoureux, S. Estimation of grain size variability with micro X-ray fluorescence in laminated lacustrine sediments, Cape Bounty, Canadian High Arctic. J. Paleolimnol. 2010, 44, 803-817. [CrossRef]

124. Balascio, N.; Zhang, Z.; Bradley, R.; Perren, B.; Dahl, S.; Bakke, J. A multi-proxy approach to assessing isolation basin stratigraphy from the Lofoten Islands, Norway. Quat. Res. 2011, 75, 288-300. [CrossRef] 
125. Brown, E. Estimation of biogenic silica concentrations using scanning XRF: Insights from studies of Lake Malawi sediments. In Micro-XRF Studies of Sediment Cores; Brown, E.T., Ed.; Springer: Dordrecht, The Netherland, 2015; pp. 267-277.

126. Shala, S.; Helmens, K.; Luoto, T.; Väliranta, M.; Weckström, J.; Salonen, J.; Kuhry, P. Evaluating environmental drivers of Holocene changes in water chemistry and aquatic biota composition at Lake Loitsana, NE Finland. J. Paleolimnol. 2014, 52, 311-329. [CrossRef]

127. Cruz, F.W.; Burns, S.J.; Jercinovic, M.; Karmann, I.; Sharp, W.D.; Vuille, M. Evidence of rainfall variations in Southern Brazil from trace element ratios $(\mathrm{Mg} / \mathrm{Ca}$ and $\mathrm{Sr} / \mathrm{Ca})$ in a Late Pleistocene stalagmite. Geochim. Cosmochim. Acta 2007, 71, 2250-2263. [CrossRef]

128. Roberts, N.; Jones, M.D.; Benkaddour, A.; Eastwood, W.J.; Filippi, M.L.; Frogley, M.R.; Lamb, H.F.; Leng, M.J.; Reed, J.M.; Stein, M.; et al. Stable isotope records of Late Quaternary climate and hydrology from Mediterranean lakes: The ISOMED synthesis. Quat. Sci. Rev. 2008, 27, 2426-2441. [CrossRef]

129. Zhang, X.; Reed, J.; Wagner, B.; Francke, A.; Levkov, Z. Lateglacial and Holocene climate and environmental change in the northeastern Mediterranean region: Diatom evidence from Lake Dojran (Republic of Macedonia/Greece). Quat. Sci. Rev. 2014, 103, 51-66. [CrossRef]

130. Unkel, I.; Schimmelmann, A.; Shrin, C.; Forsén, J.; Heymann, C.; Brückner, H. The environmental history of the last 6500 years in the asea valley (Peloponnese, Greece) and its linkage to the local archaeological record. Z. Geomorphol. 2014, 58, 89-107. [CrossRef]

131. Haberzettl, T.; Corbell, H.; Fey, M.; Janssen, S.; Lucke, A.; Mayr, C.; Ohlendorf, C.; Schabitz, F.; Schleser, G.; Wille, M.; et al. Lateglacial and Holocene wet-dry cycles in southern Patagonia: Chronology, sedimentology and geochemistry of a lacustrine record from Laguna Potrok Aike, Argentina. Holocene 2007, 17, 297-310. [CrossRef]

132. Kountoura, L.; Zacharias, I. Temporal and spatial distribution of hypoxic/seasonal anoxic zone in Amvrakikos Gulf, Western Greece. Estuar. Coast. Shelf Sci. 2011, 94, 123-128. [CrossRef]

133. Avramidis, P.; Iliopoulos, G.; Panagiotaras, D.; Papoulis, D.; Lambropoulou, P.; Kontopoulos, N.; Siavalas, G.; Christanis, K. Tracking mid- to late Holocene depositional environments by applying sedimentological, palaeontological and geochemical proxies, Amvrakikos coastal lagoon sediments, Western Greece, Mediterranean Sea. Quat. Int. 2014, 332, 19-36. [CrossRef]

134. Avramidis, P.; Bekiari, V.; Christodoulou, D.; Papatheodorou, G. Sedimentology and water column stratification in a permanent anoxic Mediterranean lagoon environment, Aetoliko Lagoon, western Greece. Environ. Earth Sci. 2014, 73, 5687-5701. [CrossRef]

135. Davis, B.A.S.; Brewer, S.; Stevenson, A.C.; Guiot, J.; Allen, J.; Almqvist-Jacobson, H.; Ammann, B.; Andreev, A.A.; Argant, J.; Atanassova, J.; et al. The temperature of Europe during the Holocene reconstructed from pollen data. Quat. Sci. Rev. 2003, 22, 1701-1716. [CrossRef]

136. Finné, M.; Holmgren, K.; Sundqvist, H.; Weiberg, E.; Lindblom, M. Climate in the eastern Mediterranean, and adjacent regions, during the past 6000 years-A review. J. Archaeol. Sci. 2011, 38, 3153-3173. [CrossRef]

137. Kaniewski, D.; Van Campo, E.; Morhange, C.; Guiot, J.; Zviely, D.; Shaked, I.; Otto, T.; Artzy, M. Early urban impact on Mediterranean coastal environments. Sci. Rep. 2013, 3, 3540. [CrossRef]

138. Wilhelm, B.; Sabatier, P.; Arnaud, F. Is a regional flood signal reproducible from lake sediments? Sedimentology 2015, 62, 1103-1117. [CrossRef]

139. Weiberg, E.; Unkel, I.; Kouli, K.; Holmgren, K.; Avramidis, P.; Bonnier, A.; Dibble, F.; Finné, M.; Izdebski, A.; Katrantsiotis, C.; et al. The socio-environmental history of the Peloponnese during the Holocene: Towards an integrated understanding of the past. Quat. Sci. Rev. 2016, 136, 40-65. [CrossRef]

140. Fossey, J.M. The pre-historique settlement by Lake Vouliagmeni. ABSA 1969, 64, 53-59.

141. Boyd, M. Speleothems in Warm Climates: Holocene records from the Caribbean and Mediterranean. Doctoral Thesis, Department of Physical Geography, Faculty of Science, Stockholm University, Stockholm, Sweden, 2015.

142. Zanchetta, G.; Regattieri, E.; Isola, I.; Drysdale, R.; Bini, M.; Baneschi, I.; Hellstrom, J.C. The so-called "4.2 event" in the central mediterranean and its climatic teleconnections. Alp. Mediterr. Quat. 2016, 29, 5-17. 
143. Katrantsiotis, C.; Kylander, M.E.; Smittenberg, R.; Yamoah, K.K.A.; Hättestrand, M.; Avramidis, P.; Strandberg, N.A.; Norström, E. Eastern Mediterranean hydroclimate reconstruction over the last 3600 years based on sedimentary n-alkanes, their carbon and hydrogen isotope composition and XRF data from the Gialova Lagoon, SW Greece. Quat. Sci. Rev. 2018, 194, 77-93. [CrossRef]

Publisher's Note: MDPI stays neutral with regard to jurisdictional claims in published maps and institutional affiliations.

(C) 2020 by the authors. Licensee MDPI, Basel, Switzerland. This article is an open access article distributed under the terms and conditions of the Creative Commons Attribution (CC BY) license (http://creativecommons.org/licenses/by/4.0/). 